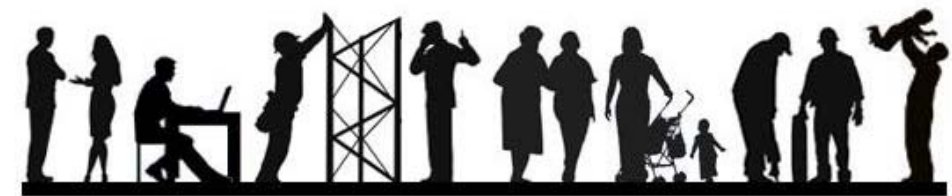

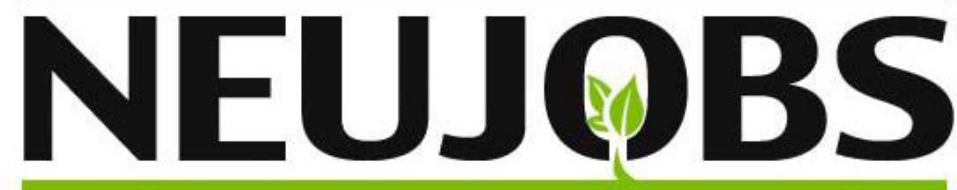

CREATING AND ADAPTING JOBS IN EUROPE IN THE CONTEXT OF A SOCIO-ECOLOGICAL TRANSITION

\section{Do the effects of pro-equality education policies differ across the performance distribution?}

\author{
By Miroslav Beblavy, Anna-Elisabeth Thum and Galina Potjagailo ${ }^{1}$ \\ NEUJOBS WORKING PAPER No. 4.5.3
}

JULY 2012

\begin{abstract}
The effect of specific education policies, such as ability grouping, preschool attendance on educational outcomes and equity has been the subject of much scholarly and political debate. Our paper adds to this debate by examining the association between such policies and equity for children of different abilities. In this way we arrive at a nuanced picture of how such specific education policies might affect different children. We study the issue at a country level for 29 OECD countries with identical methodology, enabling us to show cross-country differences. Linear regression results show that countries differ in terms of how the policy measures are correlated with equity and educational outcomes. Concentrating on equity, quantile regression results indicate that in most countries the association between education policy variables and equity is evenly distributed across the ability distribution. In some countries, however, (Austria, Spain, the US, Belgium, Latvia and Hungary) the policy variables have an especially stratifying or an especially equalising effect for the less able and in other countries for the more able. This means that ability grouping and/or participation in pre-primary education can reinforce or cushion the negative effect of a low socio-economic background more either for the more, the less able or at the median. This means that policy makers - especially in these countries mentioned - should take into account that ability grouping or participation in pre-primary education might have a different effect at different ends of the performance distribution.
\end{abstract}

\footnotetext{
${ }^{1}$ Centre for European Policy Studies, Comenius University and Université Libre de Bruxelles Corresponding author: Anna-Elisabeth Thum, Centre for European Policy Studies, Place du Congres 1, 1000 Brussels, anna.thum@ceps.eu. We would like to thank Mikkel Barslund, Orsetta Causa and Elisa Martellucci for very helpful comments.
} 


\section{1) Introduction}

Equal educational opportunity is thought to be closely linked to equal opportunities throughout life. Education is associated with a higher probability of finding a job, is positively correlated with individual earnings and economic growth (see, for instance, Card, 1999; Mincer, 1974 and Hanushek \& Luque, 2003. So if a society, a social planner or a policy-maker values the possibility of giving everyone an equal chance to succeed in life, a key objective should be to equalise educational opportunities. In the economic literature the promotion of equality of educational opportunities is usually understood as the decoupling of educational success from the family background - an interpretation that can be based on Roemer $(1998,2008)$, who defines educational equality as the independence of educational outcome from social origins. This definition expresses equality of educational opportunities in terms of equality of chances rather than of outcomes.

The education policies associated with higher equity are: the later ability tracking or streaming and promotion of early childhood education (see, for instance, OECD, 2001, 2004, 2006, 2007, 2010 and 2011 and Schuetz, Ursprung \& Woesmann, 2005; Hanushek \& Woessmann, 2005 and Woessmann, 2009). This association between specific education policies and equity leads to the OECD advising countries to postpone the age of tracking and the promotion of early childhood programmes (OECD, 2004, 2007, 2010 in Beblavy \& Veselkova, 2012). However, despite broad support for these policies, they are the subject of a scholarly and political debate about whether they should be designed to equalize outcomes (equity) or promote the elite (efficiency). Even when valuing both equity and efficiency, policy-makers are concerned that they might face a trade-off between promoting equity and efficiency ${ }^{2}$ (Woessmann, 2008:1; OECD, 2007 and Horn, 2009 in Beblavy \& Veselkova, 2012) ${ }^{3}$.

We contribute to this debate by examining how proxies (measures) of such policies (the promotion of early childhood education and late tracking) can be associated with equity across the distribution of PISA performance in a number of different countries. To this end we choose the two measures "participation in pre-primary education" and "ability-grouping within schools".

\footnotetext{
${ }^{2}$ Efficiency is understood as a setting in which a maximum amount of educational attainment is achieved with a minimal input (Woessmann, 2008:2).

${ }^{3}$ Woessmann (2008:2) argues that - depending on the education policy design - there can be a trade-off between equity and efficiency; they can be independent of each other or even complementary. He argues that such a policy makes use of the learning dynamics over the life-cycle of individuals and that it needs mainly to be output-oriented and guarantee sufficient available resources.
} 
We add to the existing literature by examining how far there is heterogeneity across countries (using linear regressions) and across the performance distribution (using quantile regressions). Distributional effects can be of interest as they are not necessarily equal: the less able students might benefit more from less ability grouping due to the peer effects from more able students, whereas the more able students might not gain as much in terms of educational performance. ${ }^{4}$ Furthermore, a cross-country comparison - enabled by using an identical methodology across countries - can reveal differences that are less evident from a cross-sectional dataset.

Our contribution to the existing literature is to extend the findings on the effect of education policies on inequality in education opportunities (measured by the socio-economic gradient) by evidence on the distributional effects of tracking and early childhood education policies on the socio-economic gradient, using the most recently available PISA database. To our knowledge it is the first paper that examines the effects of education policies on the socio-economic gradient across the ability distribution in an international comparison.

Our results are two-fold:

- Ordinary least-squares results show that countries differ in terms of how the policy measures are associated with equity and educational outcomes.

- Concentrating on equity, quantile regression results indicate that in most countries the association between education policy variables and equity is evenly distributed across the performance distribution. In some countries, however, (Austria, Spain, the US, Belgium, Latvia and Hungary) the policy measure has an especially stratifying or an especially equalising effect for the less able and in other countries for the more able. This means that ability grouping and/or participation in pre-primary education can reinforce or cushion a negative effect of a low socio-economic background either for the more, the less able or at the median. Therefore, policy-makers - especially in the countries mentioned - should take into account that ability-grouping or participation in pre-primary education might have a different effect for children situated at different ends of the performance distribution.

\footnotetext{
${ }^{4}$ Hanushek and Woessmann (2006) speak of non-linear peer effects.
} 
The remainder of the paper is organised as follows: section 2 analyses the previous findings and the relevant literature, section 3 describes our dataset and section 4 the methodology used. In section 5 we present the results and section 6 concludes.

\section{2) Previous literature}

This paper contributes to the growing literature on educational equality analysis based on the evaluation of (inter)national test scores measuring the cognitive ability of students. Some studies examine single countries and others use available international datasets such as PISA (Programme for International Student Assessment), PIRLS (Progress in International Reading Literacy) or TIMSS (Third International Mathematics and Science Study). Studies concerned with evaluating the equality of educational opportunities and their determinants can be grouped into those computing the effect of family background on test scores - this effect is commonly called the socio-economic gradient; those estimating the effect of policies on the socio-economic gradient and studies looking at the effect of school characteristics on equality or on test scores. A group of studies that is also relevant for the analysis of the effect of tracking policies is that concerned with peer effects: a benefit of late tracking can be that weaker students are strengthened by the presence of stronger students and their peer group effect. Of all the studies mentioned, some look at the average effects and others at distributional effects.

Woessmann (2004) examines the effect of family-background characteristics on student achievement in eighteen countries using quantile regression. He uses scores of The Third International Mathematics and Science Study (TIMSS) and looks at the impact of socioeconomic variables such as parents' education, the number of books at home, gender, age and immigration background on test results on a national level. He also uses quantile regression analysis to examine the heterogeneity of background effects across ability groups. He finds that the median estimates and the OLS estimate roughly coincide for most countries. At the same time the impact of family background on scores is increasing along quantiles for some countries and decreasing for a few others. Fertig (2003) also uses quantile regression to study the effects of family background on PISA test scores in Germany. Hanushek and Luque (2004) use a crosscountry approach and study the change of the effect of family background over time or age of the students, and find that in the most countries the effect of family background diminishes over time. 
A set of cross-country studies examines education policies and their effect on educational inequality in different ways. Causa and Chapuis (2009) conduct an analysis for 28 OECD countries using PISA 2006 test scores in science. As a measure of socio-economic background they use the ESCS indicator ${ }^{5}$ provided by PISA, which combines a parent's occupational status and education with the number of home possessions as income proxy. They examine the effect of the ESCS measure on test results, as well as the effect of various educational policies and their interactions with ESCS, indicating the policies' impact on inequality. They find that the socioeconomic background effect varies across countries; ability-grouping within school increases inequality and early childcare participation decreases inequality. Schuetz, Ursprung and Woessmann (2005) use the TIMSS database and find that late tracking and participation in preschool education increase educational equality. Using a combination of the PISA and PIRLS data, Hanushek and Woessmann (2004) apply a difference-in-difference methodology to eliminate cross-country differences. They find that early tracking increases inequality in education and seems to decrease the mean performance. These findings are interpreted as evidence of there being no trade-off between equity and efficiency when setting tracking at a later point in time. Ammermueller (2005) follows Hanushek and Woessmann's (2004) approach and finds that lower educational opportunities are associated with lower age in most countries and that the importance of parents' attitudes increases between primary and secondary schooling, while the importance of social origins decreases. He further finds that streaming benefits students from a better social background. Raitano and Vona (2011) find that the effects of different ability peer groups vary across different tracking schemes. Other studies analyse education policies and their effect on educational inequality on a national level. Figlio and Page (2001) examine the effects of tracking policies in the United States using the NELS database (National Educational Longitudinal Survey) and using a new methodology to overcome endogeneity issues in the tracking decision. They do not find a negative effect for tracking policy on low ability children. Betts and Shkolnik (2000) examine the effects of ability grouping on educational achievement in secondary education in the US and - contrary to the majority of the relevant literature - do not find a significant effect.

Other papers regard differences in effects of policies across the ability distribution on the national level. Muehlenweg (2007) studies the effects of secondary school tracking in Germany

\footnotetext{
${ }^{5}$ The ESCS refers to the Economic, Social and Cultural Score. See section 3 for more details.
} 
on educational outcomes by comparing the outcomes of those who were tracked after the $4^{\text {th }}$ grade and those who were tracked after the $6^{\text {th }}$ grade (participants of the so-called orientation stage) in the state of Hessen. She finds that the effects of later tracking are more positive for the low ability groups than for the rest of the ability distribution. Also using a quantile regression approach Hindricks, Verschelde, Rayp, Schoors (2010) find that school ECSC (economic and socio-cultural status of schools) has a more heterogeneous effect for pupils of lower performance in Belgium. Van Lyncker and Ghysels (2011) also examine distributional effects of early childhood education and find that there is a bias against low-income families.

A set of papers studies the effects of school characteristics on test scores. Hanushek and Luque (2003) study the effects of schools and family in a large set of countries using the TIMSS database. They find that only in some countries do school resource policies have a significant effect on educational performance. They do not find evidence that lower performance in poorer countries is likely to be due to the lower resources assigned to the schools in those countries. Cappellari (2004) studies the effect of school choice (private or public and general or technical) on educational performance in Italy and finds that general and public schools increase educational outcomes in comparison to private or technical high schools in Italy. Ooghe (2011) examines the effect of personnel subsidies in Flanders on the cognitive performance of students and finds that only spelling skills are significantly increased by the policy.

Some studies use quantile regression to assess the difference in results across the ability distribution. Basset, Tam and Knight (2002) study the econometric impact of high school characteristics on student performance using quantile regression in the US and find that high school characteristics have differing effects on achievement at different points on the achievement distribution. Eide and Showalter (1998) also use US data and find that performance at the top of the conditional distribution of maths score changes is improved by a lengthened school year while performance at the bottom of the distribution appears not to benefit from the extra class time, other things being considered equal. Collier and Millimet's (2009) look at the effects of institutional characteristics on test scores in the TIMMS data base and show that it is beneficial to study the distributional effects of institutional arrangements on education outcomes, since the effects of institutional arrangements on test scores vary across quantiles. RangvidSchindler (2007) studies the effects of a socio-economic mix on educational outcomes in Denmark and finds that school composition effects vary across ability quantiles. 
Peer group effects can have a beneficial effect on educational performance and are more likely to be present if tracking is postponed. A set of papers looks at the effect of characteristics of peer groups on educational outcomes across ability quantiles. Levin (2001) looks at the effects of class size and finds that a smaller class size emphasises peer effects. Averett and McLennan (2004) provide a comprehensive report on research and empirical findings of the effect of class size on education outcomes, drawing both from the educationalist and economic literature. Leuven and Ronning (2011) examine the effects of multi-age grouping within the same classroom and find that it has a positive effect on the performance of the whole group to mix different grades but depends on the proportion of lower and higher grades. Schneeweis and Winter-Ebmer (2007) looks at peer effects in Austrian schools and finds that positive peer effects are the largest for those with lower ability. The effect of peer effects in schools is further analysed in Toma and Zimmer (2000), Glewwe (1997) and Rivkin (2001), for example.

\section{3) Data}

Most members of the European Union are analysed, as well as Norway, the US and Japan. We use data from the PISA 2009 database, in particular from the student questionnaire and the school questionnaire. Our sample consists of 29 OECD countries. ${ }^{6}$ Each country sample consists of around 3000 to 5000 observations. ${ }^{7}$

The PISA programme tests 15-year old students in terms of their cognitive skills in mathematics, reading and science. The students' ability to apply their knowledge in different contexts is measured rather than their knowledge (Ammermueller, 2005). The databases contain background data for the students and information provided by their teachers, principals and parents. The latter questionnaires provide information on the family background, resources available at home, such as the possession of books and institutional characteristics of the schools (Ammermueller, 2005 and PISA, 2009). The sampling design is based on a two-step procedure: first the schools are selected and then students from the resulting population (the students in the school selected) are drawn randomly (Ammermueller, 2005 and PISA, 2009). The test scores are computed using a mixed coefficients multinomial logit model by Adams, Wilson and Wang (1997) in order to

\footnotetext{
${ }^{6}$ These countries are Austria, Belgium, Bulgaria, Czech Republic, Denmark, Estonia, Finland, France, Germany, Greece, Hungary, Ireland, Italy, Japan, Latvia, Lithuania, Luxemburg, Netherlands, Norway, Poland, Portugal, Romania, Slovakia, Slovenia, Spain, Sweden, Switzerland, the United Kingdom and the United States.

${ }^{7}$ Some country samples exceed this sample size and contain up to 25000 observations. All variables are available for all countries apart from ability grouping for France.
} 
produce an 'ability scale' measuring cognitive skills of the students in the sample (see PISA 2009, chapter 9 for more details). A generalised form of the Rasch model ${ }^{8}$ from item response theory is used in psychometrics to evaluate ability.

The following table gives an overview of the variables used in our analysis:

Table 1. Variable used in the analysis

\begin{tabular}{|c|c|}
\hline Variables & Description \\
\hline $\begin{array}{l}\text { PISA score } \\
\text { (mathematics, science } \\
\text { and reading) }\end{array}$ & $\begin{array}{l}\text { The PISA test scores are computed as described above, scores are } \\
\text { distributed around an international mean of } 500 \text { and a standard } \\
\text { deviation of } 100 \text { test score points. }\end{array}$ \\
\hline $\begin{array}{l}\text { ESCS score (economic, } \\
\text { cultural and social } \\
\text { score) }\end{array}$ & $\begin{array}{l}\text { The ESCS score comprises the students' answers on home } \\
\text { possessions, books in the home, parental occupation and parental } \\
\text { education expressed as years of schooling. }\end{array}$ \\
\hline $\begin{array}{l}\text { Participation in early } \\
\text { childhood education }\end{array}$ & $\begin{array}{l}\text { The students' answers on whether they attended ISCED } 0^{9} \text { education } \\
\text { are used as a measure for participation in early childhood education. }\end{array}$ \\
\hline Ability grouping & $\begin{array}{l}\text { This variable is retrieved from the PISA school questionnaire. Ability } \\
\text { grouping is measured through the school principals' indications on } \\
\text { whether ability grouping between classes exists in their school. }\end{array}$ \\
\hline ESCS school-mean & $\begin{array}{l}\text { The mean of the ESCS scores over all students within each student's } \\
\text { school, which should account for school environment effects. }\end{array}$ \\
\hline Control variables & $\begin{array}{ll}\text { - } & \text { Gender } \\
\text { - } & \text { Migration background first generation } \\
\text { - } & \text { Migration background second generation } \\
\text { - } & \text { Foreign language spoken at home } \\
\text { - } & \text { Mother at home } \\
\text { - } & \text { Father at home }\end{array}$ \\
\hline
\end{tabular}

\footnotetext{
${ }^{8}$ For a comprehensive overview of the Rasch model and other psychometric models, see Rabe-Hesketh and Skondral (2004), Generalised latent variable modeling: multilevel, longitudinal and structural equation models, Boca-Raton, FL, Chapman and Hall/CRC.

${ }^{9}$ International Standard Classification of Education 1997, http://www.uis.unesco.org/Library/Documents/isced97en.pdf
} 


\section{4) Methodology}

\subsection{Econometric model}

In order to measure the effect of potentially equalising education policies on PISA scores - both on average and over the whole conditional distribution of PISA scores - we conduct a least squares and a quantile regression analysis for each country and for each policy variable (participation in early childhood education and ability grouping), respectively. ${ }^{10}$ The test scores are regressed on the ESCS measure, the respective policy variable, as well as on the interaction effect between both, including controls for immigration background, gender, language spoken at home and whether the mother and father live at home. We further include the average ESCS effect over each school as an explanatory variable in order to account for school environment effects. ${ }^{11}$

The analysis in this paper is related to the literature using quantile regressions on a national level in order to analyse the effect of social background on achievement, as conducted by Woessmann (2004). In contrast to Woessmann (2004), who studies the effect of family background on PISA outcomes, our study focuses on the effect of measures of educational policies on students' achievement as well as on their interaction with family background, as Causa and Chapuis (2009) do for a panel data set using aggregated data across countries. The main focus is placed on providing a better understanding of how the effects of educational policies on achievement and inequality vary 1 ) over countries and 2) over the ability distributions of students for each country.

For each country the following econometric model is tested:

$$
Y_{i}=\alpha+\beta_{1} E S C S_{i}+\beta_{2} D_{i}+\beta_{3} \operatorname{ESCS}_{i} D_{i}+\beta_{4} X_{i}+\beta_{5} \sum_{i_{s}}^{I_{s}} \frac{\operatorname{ESCS}_{i_{s}}}{I_{s}}+\varepsilon_{i}
$$

where $Y_{i}$ is the individual's PISA score (in mathematics, science or reading), $E S C S_{i}$ is each individual's family background score, measured by the PISA database's economic, social and cultural score (ESCS). $D_{i}$ indicates the respective policy variable - whether the individual has

\footnotetext{
${ }^{10}$ Only the results for the mathematics scores as explanatory variable are reported. Regressions on the science and reading scores show a similar picture and are available upon request. The choice for the mathematics test scores follows Woessmann (2004: 2), who argues that the mathematics score is the most easily comparable internationally.

${ }^{11}$ This measure is created by averaging the ESCS across individuals in the respective school of the respective individual.
} 
taken part in early childhood education or whether ability grouping was present at the school the individual attended, $X_{i}$ represents the set of control variables (see section 3), $\sum_{i_{S}}^{I_{S}} \frac{E S C S_{i_{S}}}{I_{S}}$ is the mean ESCS score across individuals in school $s$ of individual $i$ and $\varepsilon_{i}$ is an error term. We are interested in the estimation of $\beta_{1}, \beta_{2}$ and $\beta_{3}$, where

- $\quad \beta_{1}$ represents the effect of family background in the PISA score. This coefficient is interpreted as the socio-economic gradient (SEG) and is a measure of equality of educational opportunity (see, for instance, Causa \& Chapuis, 2009).

- $\quad \beta_{2}$ represents the direct effect of the respective policy on the PISA score when the family background is zero (Ozer-Balli and Sorensen 2010:2).

- $\quad \beta_{3}$ represents the indirect effect of the respective policy on the PISA score. The indirect effect represents the interaction effect ${ }^{12}$ between the policy variable and the family background and therefore the effect of the respective policy variable on the effect of the family background on the PISA score.

- $\quad\left(\beta_{2}+\beta_{3} E S C S_{i}\right)$ represents the total effect (direct and indirect effect) of the respective policy on the PISA test score for a given ESCSi

We estimate the equation above for each country in our sample (29 OECD countries) by ordinary least squares to compute the mean effects and by quantile regression to estimate distributional effects (see tables A1 to A4). Quantile regression allows us to assess how independent variables affect the shape of the conditional response distribution (Koenker, 2005). In particular, we are interested in how the effect of equalising education policy variables on the socio-economic gradient varies over the conditional PISA performance distribution: in other words, we are interested in whether the effect of the education policies is of the same size for students scoring high on the PISA test as for those scoring low on the PISA test. The distributional effects can provide evidence of whether the policies have an equalising or stratifying effect in terms of educational opportunity.

In a regression model for PISA performance (as the dependent variable) in which we control for family background, own background variables and our policy of interest we are left with the

\footnotetext{
${ }^{12}$ For an excellent account of the interpretation of interaction effects, see Ozer-Balli \& Sorenson (2010).
} 
conditional PISA performance distribution. ${ }^{13}$ The error term in our model of the PISA score contains elements we did not account for in our control variables such as latent (innate) ability. Woessmann (2004) interprets this conditional PISA performance distribution as the distribution of underlying ability, or that part of ability that is not correlated with family background or policy outcomes (cf. Woessmann, 2004:15). Following this argument, henceforth we refer to the conditional PISA score distribution as the 'ability distribution'. The coefficient of a policy variable in a least-squares regression gives the average effect of the policy on the PISA score. Coefficients computed using quantile regression give the effect of the policy variable on the PISA score at different quantiles of the conditional performance distribution. Coefficients resulting from the quantile regression are therefore a measure of the degree of heterogeneity of the effect of 'policy' across the conditional performance distribution. To compute the quantile regression coefficients - just like for the ordinary least squares method - the sum of errors is minimized. However, in quantile regression it is the absolute rather than the squared sum of errors that is minimized and the sum is weighted: to compute coefficients for the lower quantiles, the lower end of the empirical conditional distribution receives more weight and for the higher quantiles the higher end of the conditional distribution receives more weight.

\subsection{Endogeneity issues}

As measures of the effects of educational policies we use two variables from the PISA questionnaires, as described in section 3:

- A variable indicating participation in pre-primary education, reported at the individual level by the respective student.

- A variable measuring the presence of ability grouping, reported at the school level by the principal.

These variables are not completely exogenous and might be subject to selectivity bias and endogeneity:

In the case of participation in pre-primary education there might be unobserved variables, such as underlying ability or parental background or preferences to support their children, that are both correlated with an explanatory variable, namely pre-primary participation and the PISA

\footnotetext{
${ }^{13}$ The distribution of the PISA score conditional on parental background variables, own background variables and the policy.
} 
score. We address these endogeneity problems in the following way: in the case of pre-primary participation, the fact that we control for the parental background by including the ESCS variable into our regression implies that factors like the higher education level of parents or the number of cultural possessions of the student's family, which might drive the pre-primary participation decision, are accounted for. Of course, this should still leave us with some unobserved characteristics, like innate ability. However, as the decision to participate in pre-primary education is generally not taken by the child but by its parents, it is rather the parents' evaluation of their child's ability than the ability itself that we omit. The parents' evaluation, in turn, should depend to a high extent on their occupation and their own educational background, which we do account for with the ESCS variable. Another argument against a strong endogeneity bias is the fact that the pre-primary participation decision is taken more than ten years prior to the PISA evaluation and also at an age level of the student at which ability should not yet have been wholly perceivable by the parents.

In the case of ability grouping our measure is based on the school principal's indication, which could be correlated with school characteristics. Here we might face the problem of reversed causality: if ability grouping is not determined on an institutional level it might be the case that it is actually not the ability grouping that lowers the school level and the individual achievement of the student, but the weak school environment that leads to the introduction of ability grouping and through the channel of contextual effects also to poor results of the student. In case of ability grouping, we try to account for this possibility by including the average level of the social background variable (ESCS) over all students from their respective school. This school average of the ESCS variable should capture school environment effects by accounting for the socioeconomic composition of the students' school and for peer effects. Nevertheless, we cannot exclude the possibility that there are some school characteristics, other than the school environment effect, that drive both the presence of ability grouping and the achievement of students, so that the implication of a causality of ability grouping on test scores should be interpreted with caution. 


\subsection{The additional value of an evaluation using quantile regression: reinforced or cushioned stratification or equalisation for different children}

The educational policy variables we study in this paper (participation in pre-primary education and ability-grouping) can also be analysed by considering the distribution of the effects across conditional performance quantiles: the direct and indirect effects of the policy variables can be pronounced to a different degree for the students at the lowest edge of the ability distribution than for those whose ability lies around the median or at the highest edge of the ability distribution.

In this sense, the above-mentioned educational policy variables might be the source of relative reinforcement or a cushioning of the policy variable effects for students situated at different ends of the performance distribution: For instance, if a negative correlation between the respective policy variable and equality is pronounced to a higher extent for students at the higher end of the performance distribution, it means that a low socio-economic background will affect more able students more than weak students. So since in this example the policy measure reinforces stratification relatively more for the more able students, it is likely that the respective policy (participation in pre-primary education or ability-grouping) reinforces stratification for the more able and in that sense talent is somewhat wasted. .

If, on the other hand, a negative correlation between the respective policy and equality is pronounced to a greater extent for students at the lower end of the performance distribution, it means that a low socio-economic background will affect the less able students more than stronger students and in that sense the policy effect is reinforced for the less able - relative to the more able students.

\section{5) Results}

In this section we concentrate on our findings on 1) the association of pre-primary education participation and of ability grouping with test scores, 2) the association of these policy variables with equality of educational opportunities on average and across quantiles.

This section is organised as follows: first we analyse the results obtained by ordinary least squares - indicating the differences across countries in terms of effects of the policy variables on 
equity and efficiency - and by quantile regression - indicating the difference in effect of the policy variables on equity across the ability distribution.

\subsection{Ordinary least squares results: equity vs. efficiency}

Figures 1 and 2 below show the effects of the policy outcome variables (pre-primary education and ability grouping) on the PISA score (efficiency) and on the socio-economic gradient (equity). ${ }^{14}$

We find that 1) the effect of participation in pre-primary education on test scores is mostly positive (or insignificant) across the 29 countries and the effect of ability grouping on test scores is ambiguous across countries, 2) the effect of pre-primary education and ability grouping on equality of educational opportunities (measured by the socio-economic gradient) is ambiguous across countries. In terms of correlations of the policy measures with equality we find that in most countries both policy variables are more likely to be positively correlated with inequality.

For each of the two education policies considered, we can group countries according to different scenarios:

- In some countries the respective education policy variable (participation in pre-primary education or ability-grouping) has unambiguously positive effects in the sense that it improves students' test scores and at the same time decreases inequality ('best-case scenarios’).

- In another group of countries the respective policies have a negative impact on students' test scores and moreover increase inequality in students' results by increasing the impact of the socio-economic gradients ('worst-case scenarios').

- In a last group of countries, there are equity-efficiency trade-offs in the sense that the respective education policy improves test scores, but at the same time increases inequality or vice versa, it decreases test scores but decreases inequality (countries facing 'trade-offs').

In both Figures 1 and 2 the best place to be ('best-case' countries) is in the lower right side corner: the policy is positively correlated with both PISA outcomes and an increase in equality (a decrease in the socio-economic gradient). The upper right side corner contains countries in which

\footnotetext{
${ }^{14}$ Tables A3 and A4 in the appendix show the full results obtained by ordinary least squares regressions.
} 
the respective policy is positively correlated with the PISA score but negatively correlated with equity (the policy-maker would face a trade-off). The upper left quadrant contains countries in which the policy is negatively correlated with the PISA score and also with equality (these are the 'worst-case' countries). Finally, the lower left side quadrant contains countries in which the respective policy is negatively correlated with the PISA score and positively with equality ('trade-off' countries).

The best case country in Figure 1 is Spain: participation in pre-primary education is positively significantly correlated with PISA scores and equality. Among these 'best-case' countries is one other Mediterranean country (Italy), two Central-European countries (Czech Republic and Slovakia), one conservative country (Luxembourg) and Japan and the US. The 'worst case' countries in terms of pre-primary education are Estonia, Finland, Ireland, the Netherlands and Slovenia. Most countries face a trade-off between a positive correlation with the PISA score and a negative correlation with equality. Latvia and Lithuania face a trade-off between a negative correlation with the PISA score and a positive correlation with equality. However, as Tables A3 and A4 show, not all effects are significant: countries with significant coefficients of equality are Denmark, Germany, Norway, Romania, Slovakia, Spain and the United Kingdom.

Figure 1. The effects of pre-primary education on the PISA score and on the socio-economic gradient

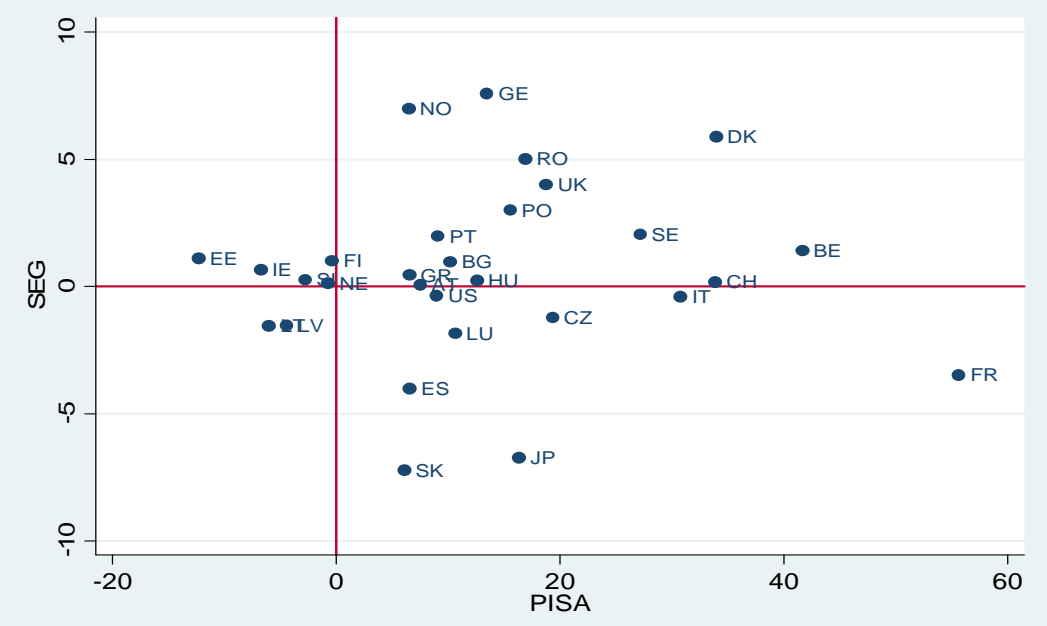

Source: Own calculations from tables A3 and A4.

In terms of ability grouping - depicted in Figure 2 - there is no country in the 'best-case' quadrant: in no country is ability grouping associated with both an increase in the PISA score 
and in equality. Most countries are on the trade-off axis. A group of conservative countries (Austria, Germany, the Netherlands, and Portugal) are in the 'worst-case’ quadrant: ability grouping is associated with both a decrease in the PISA score and in equality. Trade-offs between the effects of ability grouping on equality or on outcomes are faced by Belgium, Hungary, Romania and the United States.

Figure 2. The effects of ability grouping on the PISA score and on the socio-economic gradient

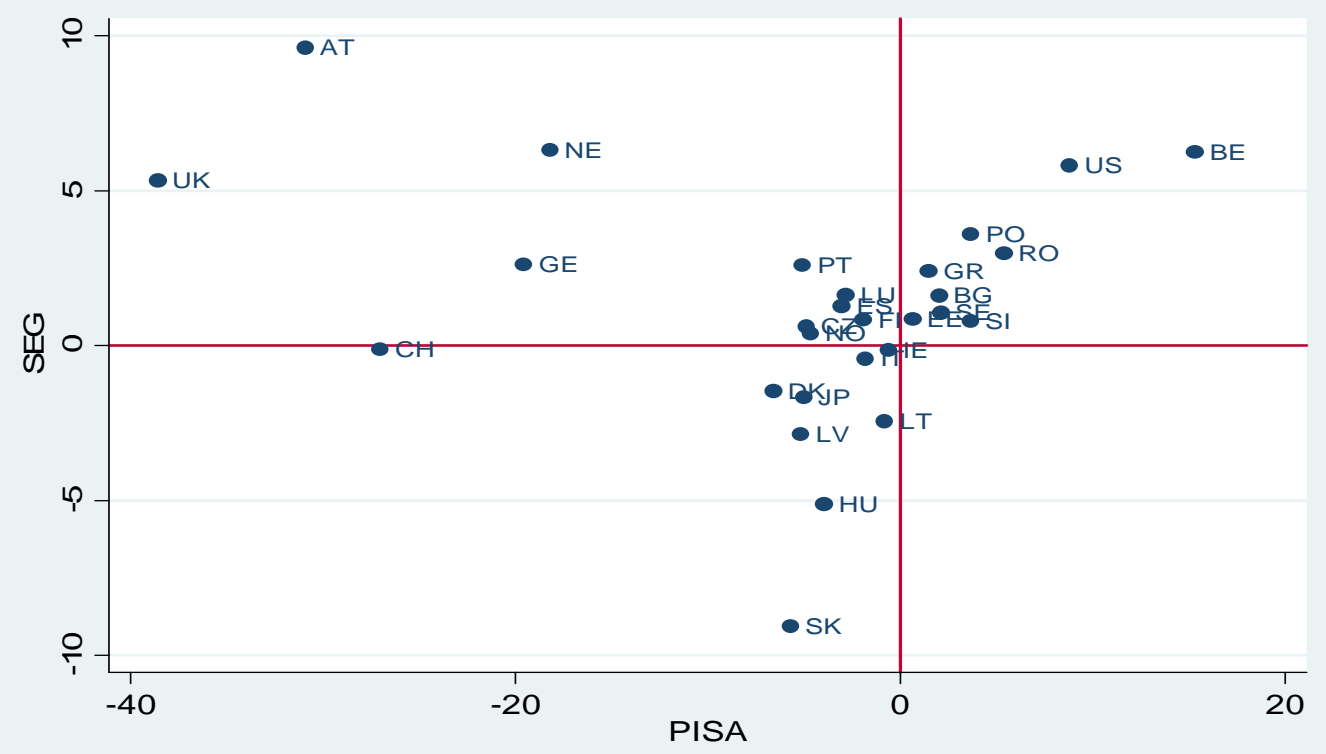

Source: Own calculations from tables A3 and A4.

The results in this section show that less ability grouping and participation in pre-primary education are not necessarily associated with lower inequality of educational opportunities in all countries. The difference in results to what some of the previous literature has found can be due to the fact that we look at countries separately, that we use a proxy for tracking - namely within school ability grouping - and that we might use a different definition of inequality from other authors (Hanushek and Woessmann, 2005, study the dispersion of PISA outcomes, for instance). 


\subsection{Quantile Regression Results: equalisation across the conditional ability distribution?}

The results can be depicted in a set of graphs for each country which are shown in Figures A1 and A2. ${ }^{15} \mathrm{~A}$ first view of the graph shows the quantile results differ across countries and that in some countries they vary considerably across the conditional ability distribution. In Tables 1 and 2 we group countries more systematically into those with a relatively large variation and those with no strong difference across the quantiles. We first analyse ability grouping and then preprimary education.

\section{Ability grouping}

Table 2. Country grouping of the effect of ability grouping on the socio-economic gradient

\begin{tabular}{|c|c|c|}
\hline $\begin{array}{l}\text { Effect of ability } \\
\text { grouping on } \\
\text { equality }\end{array}$ & $\begin{array}{l}\text { mostly decreasing equality } \\
\text { (increasing the socio- } \\
\text { economic gradient) }\end{array}$ & $\begin{array}{l}\text { mostly increasing } \\
\text { equality (decreasing } \\
\text { the socio-economic } \\
\text { gradient) }\end{array}$ \\
\hline $\begin{array}{l}\text { stronger for less } \\
\text { able }\end{array}$ & $\mathrm{BE}(*), \mathrm{EE}, \mathrm{SE}$ & IE, LV(*), JP \\
\hline $\begin{array}{l}\text { no strong difference } \\
\text { across quantiles or } \\
\text { median effect } \\
\text { strongest }\end{array}$ & $\begin{array}{l}\mathrm{BG}, \mathrm{CZ}, \mathrm{DE}\left({ }^{*}\right) \mathrm{LU}, \\
\mathrm{NL}(*), \mathrm{PL}, \mathrm{PT}(*), \mathrm{RO}(*), \\
\mathrm{ES}\left({ }^{*}\right), \mathrm{UK}(*)\end{array}$ & $\begin{array}{l}\text { DK, FI, GR,IE, IT, } \\
\text { JP, LT (*), NO, } \\
\text { SK(*),SI, CH }\end{array}$ \\
\hline $\begin{array}{l}\text { stronger for more } \\
\text { able }\end{array}$ & $\mathrm{AT}(*), \mathrm{US}(*)$ & $\mathrm{HU}(*)$ \\
\hline
\end{tabular}

Notes: * indicates significance of the effects on equity or on PISA (at least at 1 quantile); any difference larger than 3 is considered as non-neutral across the quantiles

Table 2 shows that in most countries with a significant association between ability grouping and inequality, the correlation is positive. In Hungary, Lithuania, Latvia and Slovakia, however ability grouping is significantly associated with lower inequality. In most countries the correlation between ability grouping and equity is similar across quantiles but in some countries (Belgium, Austria, Hungary, Latvia and the US) the effect varies more strongly across the

\footnotetext{
${ }^{15}$ In tables A1 and A2 we show our findings for quantile regressions at the $20 \%, 50 \%$ and the $80 \%$ quantiles of the ability distribution. Results from science and reading scores are also available upon request. We choose to report mathematics scores due to their international comparability (see Woessmann, 2004:2).
} 
quantiles. These countries with a stronger variation across quantiles can be grouped in four different cases:

First Case (the US and Austria): in these countries ability grouping is positively correlated with the effect of the socio-economic background on the PISA score, which means that the policy will reinforce the effect of the socio-economic background. Furthermore, in these countries, social stratification is reinforced by ability grouping mostly for the more able: for a more able child with a low socio-economic background, ability grouping will reinforce the negative effect of the low socio-economic background characteristics more than for a less able child and vice versa. A high socio-economic background has a stronger effect for the more able than for the less able. So one can say that in these countries it likely that the talent of a more able child from a low socioeconomic background will be not be used properly due to ability grouping. On the other hand, ability grouping will not affect equality for the less able (the effect is insignificant).

Second case (Belgium): in Belgium, ability grouping reinforces stratification more for the less able than for the more able: for the less able children from a favourable socio-economic background, ability grouping will reinforce a positive family background effect, but less able students with a low socio-economic background are the worst off since their low socio-economic background is reinforced and they are less able.

Third case (Latvia): in Latvia ability grouping is associated with higher equity and this is more so for the more able students. So the policy does reduce the effect of family background but mostly for the more able students.

Fourth case (Hungary): in Hungary, as in Latvia, ability grouping is associated with higher equality but ability grouping equalises educational opportunities more for the able.

Latvia would be a 'compressing' country: ability grouping increases equality and more so for the less able. In other words, a less able student will have the bad luck of being less able but ability grouping will reduce the negative effect of a less favourable family background or increase the effect of a favourable family background rather more. For the more able this equalising effect is not so strong. Belgium on the other hand would be a 'polarising' country: ability grouping stratifies and does so mostly for those at the lower end of the performance distribution

\section{Pre-primary education}


Table 3. Country grouping of the effect of pre-primary education on the socio-economic gradient

\begin{tabular}{|c|c|c|}
\hline $\begin{array}{l}\text { Effect of pre-primary } \\
\text { education on equality }\end{array}$ & $\begin{array}{c}\text { mostly decreasing } \\
\text { equality (increasing the } \\
\text { socio-economic } \\
\text { gradient) }\end{array}$ & $\begin{array}{l}\text { mostly increasing } \\
\text { equality (decreasing } \\
\text { the socio-economic } \\
\text { gradient) }\end{array}$ \\
\hline stronger for less able & $\begin{array}{l}\mathrm{BE}(* \text {, negative for } 0.8 \\
\text { quantile), } \operatorname{LT}(*), \operatorname{PT}(*)\end{array}$ & $\begin{array}{l}\mathrm{DE}, \mathrm{JP}, \mathrm{NL}, \mathrm{ES}(* \\
\text { increasing equality for } \\
\text { the } 0.2 \text { quantile) }\end{array}$ \\
\hline $\begin{array}{l}\text { no strong difference } \\
\text { across quantiles or } \\
\text { median effect strongest }\end{array}$ & $\begin{array}{l}\text { AT, BG, DK(*), EE, } \\
\text { FI, FR(*), GR, HU, } \\
\text { LV, NO(*), PL(*), RO, } \\
\text { SI, SE, UK(*) }\end{array}$ & $\begin{array}{l}\text { CZ, IE, IT, LU, } \\
\mathrm{SK}(*), \mathrm{CH}\end{array}$ \\
\hline stronger for more able & $\mathrm{ES}(*)$ & US \\
\hline
\end{tabular}

Notes: * indicates significance of the effects on equity or on PISA (at least at 1 quantile); any difference larger than 3 is considered as non-neutral across the quantiles

Table 3 shows that in most countries with a significant association between pre-primary education and inequality, the correlation is positive - given our controls for family background and high school background. In Hungary, Lithuania, Latvia and Slovakia and Spain, however, pre-primary education is significantly associated with lower inequality. In most countries the correlation between pre-primary education and equity is similar across quantiles but in some countries (Belgium, Lithuania, Portugal and Spain) the effect varies more strongly across the quantiles. These countries with a stronger variation across quantiles can be grouped into two different cases:

First case (Belgium, Lithuania and Portugal): in these countries pre-primary education is associated with decreasing equality for the less able even though the effect is insignificant if one regards the average OLS results (see Table A3). Pre-primary education stratifies more for the less able implying that a less favourable socio-economic background is especially negative for the less able.

Second case (Spain): in Spain pre-primary education is associated with higher equality for the less able: for the less able a lower socio-economic background disadvantages the less able to a lesser degree than the more able. 
Belgium, Lithuania and Portugal on the other hand would be seen as 'polarising' countries since pre-primary education stratifies more for the less able. In Spain, pre-primary education equalises for the less able and stratifies for the more able and we therefore see it as a 'compressing' country.

Comparing both policies, we find that none of the two policies is unambiguously positive or negatively associated with equity across the countries in our sample. In slightly more countries ability grouping has an effect that varies across the conditional performance distribution than pre-primary education, implying that it might be marginally more likely that ability grouping has a differing effect for different children.

\section{6) Conclusion}

In this paper we set out to investigate the association of measures of equalising educational policies with equality of educational opportunity across the ability distribution by examining the distributional effect of an interaction term between a family background indicator and the respective policy measure.

We find that 1) the correlation of participation in pre-primary education with PISA test scores is mostly positive (or insignificant) across the 29 countries and the effect of ability grouping on test scores is ambiguous across countries; 2) the correlation of pre-primary education and ability grouping with equality of educational opportunities (measured by the socio-economic gradient) is ambiguous across countries; 3) countries can be grouped according to their correlations with test scores and equity. We find that there are

- $\quad$ countries with 'best-case scenarios', in which the respective policy is associated both with higher test scores and equality of educational opportunities (Spain and Slovakia in terms of pre-primary education),

- countries with 'worst-case' scenarios, in which the respective policy measure is associated both with lower test scores and equality (Austria, Portugal and the Netherlands in terms of ability grouping)

- countries which face trade-offs between equity and efficiency (Denmark, Germany, Norway, the UK in terms of pre-primary education, and Belgium, Hungary, Romania, Slovakia and the US in terms of ability grouping). 
Finally, 4) the effect of either of the two education policy measures (ability grouping or preprimary education) on equality of educational opportunities is not the same across the ability distribution - meaning that an equalising or a stratifying effect of a policy can be stronger or weaker for less able or for highly able students: concentrating on the equity dimension, quantile regression results indicate that in most countries the effects of the policies are distributed evenly across quantiles, but not in all. We find that in some countries (Austria, the US and Spain) it needs to be considered that one of the two policy measures studied is correlated with more inequality, especially for more able children: talent might be wasted if the socio-economic background is low. In Belgium it needs to be considered that one of the two policies studied is correlated with more inequality, especially for less able children: stratification is reinforced for the less able. In Latvia one of the policies is correlated with higher equality especially for the less able: the policy has a beneficial effect, especially for the less able. In Hungary one of the policy measures is correlated with a higher equality especially for the more able: the policy has a beneficial effect especially for the more able. Policy-makers - especially in these countries mentioned - should take into account that the policy might have a different effect for different children. 


\section{References}

Adams, R., Wilson, M., \& Wang, W. (1997), The Multidimensional random coefficients multinomial logit model, Applied Psychological Measurement, 21(1), 1-23

Ammermüller, A. (2005), Educational Opportunities and the Role of Institutions, ZEW Discussion Papers 05-44, ZEW - Zentrum für Europäische Wirtschaftsforschung / Center for European Economic Research

Averett S. L. and McLennan M.C. (2004), "Exploring the effects of class size on student achievement: what have we learned over the past two decades?” in Geraint J. and Johns J. (Eds), International handbook on the economics of education, Cheltenham: Edward Elgar, pp. 329367.

Bassett, G.W., Tam, M.-Y. and Knight, K. (2002) “Quantile models and estimators for data analysis” International Journal for Theoretical and Applied Statistics, Volume 55, 2002, 17-26.

Betts JR, Shkolnik JL. (2000) “The effects of ability grouping on student achievement and resource allocation in secondary schools" in Economics of Education Review 19(1):1-15.

Beblavy, M. and Veselkova, M. (2012): From selectivity to universalism: the political economy of educational reform, FISS Conference paper, Sigtuna, Sweden June 2012.

Cappellari, L. (2004), High school types, academic performance and early labour market outcomes, CHILD Working Papers wp03_04, CHILD - Centre for Household, Income, Labour and Demographic economics - Italy.

Card, D. (1999): The causal effect of education on earnings, in O. Aschenfelter and D. Card, Handbook of Labor Economics, Vol 3A: 1801-1863, Amsterdam, Elsevier.

Causa, O. and Chapuis C. (2009): Equity in student achievement across OECD countries an investigation of the role of policies, OECD.

Collier, T. and Millimet, D. (2009), "Institutional arrangements in educational systems and student achievement: A cross-national analysis”. Empirical Economics, 37(2), 329-381.

Edwin L., and Marte R. (2011), Classroom Grade Composition and Pupil Achievement, IZA Discussion Papers 5922, Institute for the Study of Labor (IZA). 
Eide, E., Showalter M.H. (1998): “The effect of school quality on student performance: A quantile regression approach”. Economics Letters, Vol. 58, No. 3, pp. 345-350.

Fertig, M. (2003), Who’s to blame? The determinants of German Students’ Achievement in the PISA 2000 Study. IZA Discussion Paper 739. Bonn: Institute for the Study of Labor.

Figlio D. N. and Page M. E. (2000), School Choice and the Distributional Effects of Ability Tracking: Does Separation Increase Equality?, NBER Working Papers 8055, National Bureau of Economic Research, Inc.

Glewwe, P. (1997), "Estimating the impact of peer group effects on socioeconomic outcomes: Does the distribution of peer group characteristics matter?" Economics of Education Review, Elsevier, vol. 16(1), pages 39-43, February.

Hanushek, E. A. and, J.A. Luque., 2003. "Efficiency and equity in schools around the world," Economics of Education Review, Elsevier, vol. 22(5), pages 481-502, October.

Hanushek, E.A. and L. Woessmann (2005). "Does Educational Tracking Affect Performance and Inequality? Differences-in-Differences Evidence across Countries," NBER Working Papers, 11124, National Bureau of Economic Research, Inc.

Hindriks J. G., Verschelde M., Rayp G., and Schoors K. (2010), School tracking, social segregation, and educational opportunity: evidence from Belgium, CORE DP n²010-8.

Koenker, R. (2005) "Quantile Regression," Cambridge Books, Cambridge University Press, number 9780521608275, 7.

Levin J. (2001). "For whom the reductions count: A quantile regression analysis of class size and peer effects on scholastic achievement," Empirical Economics, Springer, vol.26(1), pages 221246.

Leuven, E. and M. Ronning (2011): Classroom Grade Composition and Pupil Achievement, IZA Discussion Paper no. 5922, Institute for the Future of Labor, Bonn, Germany.

Mincer, J. (1974) Schooling, Experience and Earnings. New York: Columbia University Press (for NBER) 
Mühlenweg, A. (2007), Educational Effects of Early or Later Secondary School Tracking in Germany, ZEW Discussion Paper No. 07-079, Mannheim.

OECD (2001), Starting Strong I: Early Childhood Education and Care, OECD, Paris.

OECD (2004), Learning for tomorrow’s world - first results from PISA 2003, OECD, Paris.

OECD (2006), Starting Strong II: Early Childhood Education and Care, OECD, Paris.

OECD (2007), PISA 2006: Science competencies for tomorrow’s world, OECD, Paris.

OECD (2010), PISA 2009 results: overcoming social background - equity in learning opportunities and outcomes (volume II), OECD, Paris.

OECD (2011), PISA in Focus 1: Does participation in pre-primary education translate into better learning outcomes at school?, OECD, Paris.

Ooghe, E. (2011), The impact of ‘equal educational opportunity’ fund: a regression discontinuity design. CES - Discussion paper series DPS11.08, pp. 1-22.

Ozer-Balli, H. and Sorensen B. E. (2010), Interaction Effects in Econometrics, CEPR Discussion Paper No. DP7929.

PISA (2009), Technical Report. Available from http://www.oecd.org/document/19/0,3746,en_2649_35845621_48577747_1_1_1_1,00.html

Rabe-Hesketh, S. and Skondral. A (2004), Generalised latent variable modelling: multilevel, longitudinal and structural equation models, Boca-Raton, FL, Chapman and Hall/CRC.

Raitano, M. and Vona, F. (2010): Peer Heterogeneity, Parental Background and Tracking: Evidence from PISA 2006. Documents de Travail de l'OFCE 2010-23, Observatoire Francais des Conjonctures Economiques (OFCE).

Rangvid-Schindler B. (2007), "School composition effects in Denmark: quantile regression evidence from. PISA 2000”, Empirical Economics 32: 359-386.

Rivkin, S. (2001), Tiebout Sorting, Aggregation and the Estimation of Peer Group Effects, Economics of Education-Review 20 (3), 201-09. 
Roemer, J.E. (1998), Equality of Opportunity, Cambridge, MA: Harvard University Press.

Roemer, J.E. (2008): “Equality of opportunity.” The New Palgrave Dictionary of Economics Online. Palgrave Macmillan. Available from

http://www.dictionaryofeconomics.com/article?id=pde2008_E000214 (Accessed 29.Nov. 2011)

Schneeweis N., and Winter-Ebmer R. (2007), "Peer effects in Austrian schools," Empirical Economics, Springer, vol. 32(2), pages 387-409, May.

Schütz G. and Ursprung H.and Woessmann L. (2005), Education Policy and Equality of Opportunity, Munich: CESifo Working Paper Series No. 1518.

Toma, E. and Zimmer R (2000), "Peer Effects in Private and Public Schools Across Countries”, Journal of Policy Analysis and Management 19 (1), 75-92.

Van Lancker, W. and Ghysels, J. (2011), Who reaps the benefits? The social distribution of public childcare in Sweden and Flanders, GINI discussion paper 10, June 2011.

Woessman, L. (2004), How equal are educational opportunities? Family background and student achievement in Europe and the US, Munich: CESifo Working Paper No.1162

Woessmann, L. (2008): Efficiency and equity of European education and training policies, International Tax and Public Finance 15(2), pp.199-230

Woessmann, L. (2009): International evidence on school tracking: a review, Munich: CESifo DICE Report 1/2009:26-34. 


\section{Appendix}

Table A1: Regressions of PISA 2009 Mathematics test scores, on the socio-economic gradient, ability grouping and their interaction. Quantile regressions for 20 percent, 50 percent and 80 percent quantile.

\begin{tabular}{|c|c|c|c|c|c|c|c|c|c|c|c|c|}
\hline & \multicolumn{3}{|c|}{ ESCS } & \multicolumn{3}{|c|}{ m_ESCS } & \multicolumn{3}{|c|}{ Interaction } & \multicolumn{3}{|c|}{ ABGROUP } \\
\hline & $\mathrm{q} 20$ & q50 & q80 & q20 & q50 & q80 & q20 & q50 & q80 & $\mathrm{q} 20$ & q50 & q80 \\
\hline AT & $\begin{array}{l}\text { 7.630** } \\
(3.859)\end{array}$ & $\begin{array}{l}1.067 \\
(2.554)\end{array}$ & $\begin{array}{l}-0.932 \\
(2.736)\end{array}$ & $\begin{array}{c}79.27 * * * \\
(5.690)\end{array}$ & $\begin{array}{c}96.28 * * * \\
(4.479)\end{array}$ & $\begin{array}{c}\text { 94.19*** } \\
(2.792)\end{array}$ & $\begin{array}{c}1.567 \\
(4.038)\end{array}$ & $\begin{array}{c}\mathbf{1 1 . 9 6 * * *} \\
(3.013)\end{array}$ & $\begin{array}{c}15.26 * * * \\
(2.834)\end{array}$ & $\begin{array}{c}-38.57 * * * \\
(3.278)\end{array}$ & $\begin{array}{c}-33.96 * * * \\
(2.289)\end{array}$ & $\begin{array}{c}-30.98 * * * \\
(2.889)\end{array}$ \\
\hline $\mathrm{BE}$ & $\begin{array}{c}\mathbf{9 . 8 6 3} * * * \\
(2.153)\end{array}$ & $\begin{array}{c}\mathbf{9 . 8 2 8} * * * \\
(1.827)\end{array}$ & $\begin{array}{c}9.333^{* * *} \\
(2.351)\end{array}$ & $\begin{array}{c}107.0 * * * \\
(3.528)\end{array}$ & $\begin{array}{c}\text { 95.16*** } \\
(3.016)\end{array}$ & $\begin{array}{c}\text { 81.50*** } \\
(2.385)\end{array}$ & $\begin{array}{c}9.333^{* * *} \\
(2.542)\end{array}$ & $\begin{array}{c}6.167 * * * \\
(2.334)\end{array}$ & $\begin{array}{l}5.215 * * \\
(2.207)\end{array}$ & $\begin{array}{c}19.53 * * * \\
(2.830)\end{array}$ & $\begin{array}{c}\mathbf{1 8 . 0 8}^{* * * *} \\
(2.446)\end{array}$ & $\begin{array}{c}\mathbf{1 2}^{\mathbf{1 2 . 7 1}} \text { (3.126) } \\
\text { (3.126) }\end{array}$ \\
\hline BG & $\begin{array}{c}\mathbf{2 0 . 6 1} * * * \\
(2.959)\end{array}$ & $\begin{array}{c}20.22 * * * \\
(2.603)\end{array}$ & $\begin{array}{c}18.64 * * * \\
(2.734)\end{array}$ & $\begin{array}{c}77.49 * * * \\
(4.216)\end{array}$ & $\begin{array}{c}\text { 76.32*** } \\
(2.921)\end{array}$ & $\begin{array}{c}\text { 74.81*** } \\
(4.929)\end{array}$ & $\begin{array}{c}1.223 \\
(2.787)\end{array}$ & $\begin{array}{c}2.695 \\
(2.739)\end{array}$ & $\begin{array}{c}2.983 \\
(2.165)\end{array}$ & $\begin{array}{c}0.837 \\
(4.195)\end{array}$ & $\begin{array}{l}-1.713 \\
(1.832)\end{array}$ & $\begin{array}{c}3.941 \\
(3.040)\end{array}$ \\
\hline $\mathrm{CZ}$ & $\begin{array}{c}\text { 18.00*** } \\
(4.278)\end{array}$ & $\begin{array}{c}\text { 12.73*** } \\
(4.075)\end{array}$ & $\begin{array}{c}13.26 * * * \\
(4.039)\end{array}$ & $\begin{array}{c}\text { 135.7*** } \\
(5.959)\end{array}$ & $\begin{array}{c}\text { 146.5*** } \\
(4.112)\end{array}$ & $\begin{array}{c}134.5^{* * *} \\
(5.863)\end{array}$ & $\begin{array}{l}0.0828 \\
(4.888)\end{array}$ & $\begin{array}{c}5.252 \\
(3.267)\end{array}$ & $\begin{array}{c}3.084 \\
(3.656)\end{array}$ & $\begin{array}{l}-2.257 \\
(2.618)\end{array}$ & $\begin{array}{c}-7.765 * * \\
(3.548)\end{array}$ & $\begin{array}{l}-3.330 \\
(4.178)\end{array}$ \\
\hline DE & $\begin{array}{c}\mathbf{1 0 . 4 6 * * *} \\
(3.396)\end{array}$ & $\begin{array}{c}\text { 12.55*** } \\
(3.437)\end{array}$ & $\begin{array}{c}\mathbf{8 . 0 6 0}^{* * *} \\
(2.456)\end{array}$ & $\begin{array}{c}\text { 104.5*** } \\
(5.455)\end{array}$ & $\begin{array}{c}105.9 * * * \\
(4.318)\end{array}$ & $\begin{array}{c}\text { 103.2*** } \\
(3.867)\end{array}$ & $\begin{array}{c}2.639 \\
(3.127)\end{array}$ & $\begin{array}{c}1.215 \\
(2.965)\end{array}$ & $\begin{array}{l}4.252^{*} \\
(2.420)\end{array}$ & $\begin{array}{c}-\mathbf{1 8 . 6 7}^{* * *} \\
(3.784)\end{array}$ & $\begin{array}{c}\mathbf{- 1 3 . 4 7 * * *} \\
(3.201)\end{array}$ & $\begin{array}{c}-20.92 * * * \\
(4.374)\end{array}$ \\
\hline DK & $\begin{array}{c}23.26 * * * \\
(2.915)\end{array}$ & $\begin{array}{c}29.06 * * * \\
(2.279)\end{array}$ & $\begin{array}{c}\text { 26.70*** } \\
(3.113)\end{array}$ & $\begin{array}{c}30.45 * * * \\
(5.720)\end{array}$ & $\begin{array}{c}\text { 28.13**** } \\
(2.817)\end{array}$ & $\begin{array}{c}29.17 * * * \\
(2.857)\end{array}$ & $\begin{array}{l}-2.044 \\
(2.663)\end{array}$ & $\begin{array}{l}-1.479 \\
(2.495)\end{array}$ & $\begin{array}{l}-1.305 \\
(3.306)\end{array}$ & $\begin{array}{c}-5.412^{* *} \\
(2.528)\end{array}$ & $\begin{array}{c}-5.005^{* *} \\
(2.520)\end{array}$ & $\begin{array}{c}-\mathbf{9 . 3 5 6 * * *} \\
(3.090)\end{array}$ \\
\hline EE & $\begin{array}{c}17.70^{* * *} \\
(2.815)\end{array}$ & $\begin{array}{c}14.93^{* * *} \\
(2.700)\end{array}$ & $\begin{array}{c}\text { 16.98*** } \\
(3.597)\end{array}$ & $\begin{array}{c}55.84 * * * \\
(5.354)\end{array}$ & $\begin{array}{c}\text { 47.94*** } \\
(5.815)\end{array}$ & $\begin{array}{c}44.09 * * * \\
(4.572)\end{array}$ & $\begin{array}{l}-2.083 \\
(3.146)\end{array}$ & $\begin{array}{l}4.329 * \\
(2.368)\end{array}$ & $\begin{array}{c}1.177 \\
(3.265)\end{array}$ & $\begin{array}{c}5.172 \\
(4.098)\end{array}$ & $\begin{array}{l}-1.015 \\
(3.710)\end{array}$ & $\begin{array}{l}-2.364 \\
(2.485)\end{array}$ \\
\hline FI & $\begin{array}{c}23.15 * * * \\
(2.874)\end{array}$ & $\begin{array}{c}23.99 * * * \\
(2.345)\end{array}$ & $\begin{array}{c}27.04 * * * \\
(2.322)\end{array}$ & $\begin{array}{l}\text { 11.00* } \\
(6.677)\end{array}$ & $\begin{array}{c}4.929 \\
(3.923)\end{array}$ & $\begin{array}{c}\text { 10.78** } \\
(4.988)\end{array}$ & $\begin{array}{l}-1.110 \\
(3.354)\end{array}$ & $\begin{array}{l}1.442 \\
(3.249)\end{array}$ & $\begin{array}{l}-2.977 \\
(3.274)\end{array}$ & $\begin{array}{l}-0.880 \\
(3.773)\end{array}$ & $\begin{array}{l}-1.339 \\
(3.458)\end{array}$ & $\begin{array}{l}-1.487 \\
(3.657)\end{array}$ \\
\hline GR & $\begin{array}{c}\mathbf{1 1 . 4 9 * * *} \\
(2.107)\end{array}$ & $\begin{array}{c}\text { 18.32*** } \\
(2.354)\end{array}$ & $\begin{array}{c}21.96 * * * \\
(2.530)\end{array}$ & $\begin{array}{c}\mathbf{5 1 . 6 5 * * *} \\
(3.183)\end{array}$ & $\begin{array}{c}\text { 43.26*** } \\
(2.406)\end{array}$ & $\begin{array}{c}38.56 * * * \\
(4.392)\end{array}$ & $\begin{array}{c}3.035 \\
(2.641)\end{array}$ & $\begin{array}{l}-0.630 \\
(3.353)\end{array}$ & $\begin{array}{l}-0.421 \\
(5.692)\end{array}$ & $\begin{array}{c}3.507 \\
(5.040)\end{array}$ & $\begin{array}{c}3.712 \\
(4.277)\end{array}$ & $\begin{array}{l}-2.916 \\
(5.083)\end{array}$ \\
\hline HU & $\begin{array}{l}\text { 7.087* } \\
(3.958)\end{array}$ & $\begin{array}{c}\text { 12.43*** } \\
(2.946)\end{array}$ & $\begin{array}{c}15.95 * * * \\
(2.664)\end{array}$ & $\begin{array}{c}89.50 * * * \\
(4.005)\end{array}$ & $\begin{array}{c}\mathbf{8 8 . 1 5 * * *} \\
(2.373)\end{array}$ & $\begin{array}{c}\mathbf{8 7 . 4 2 * * *} \\
(3.500)\end{array}$ & $\begin{array}{l}-2.198 \\
(2.434)\end{array}$ & $\begin{array}{l}-4.919 * \\
(2.743)\end{array}$ & $\begin{array}{c}-\mathbf{7 . 0 2 8} * * * \\
(2.519)\end{array}$ & $\begin{array}{l}-4.615 \\
(3.671)\end{array}$ & $\begin{array}{l}-3.949 \\
(2.847)\end{array}$ & $\begin{array}{l}-2.365 \\
(3.214)\end{array}$ \\
\hline IE & $\begin{array}{l}\text { 22.09* } \\
(11.68)\end{array}$ & $\begin{array}{c}30.57 * * * \\
(5.513)\end{array}$ & $\begin{array}{c}32.67 * * * \\
(7.523)\end{array}$ & $\begin{array}{c}\mathbf{4 0 . 9 0 * * *} \\
(5.716)\end{array}$ & $\begin{array}{c}27.74 * * * \\
(4.545)\end{array}$ & $\begin{array}{c}25.63^{* * *} \\
(5.524)\end{array}$ & $\begin{array}{c}5.892 \\
(11.23)\end{array}$ & $\begin{array}{l}-3.760 \\
(4.454)\end{array}$ & $\begin{array}{l}-5.217 \\
(6.348)\end{array}$ & $\begin{array}{c}6.422 \\
(8.382)\end{array}$ & $\begin{array}{l}-2.065 \\
(9.067)\end{array}$ & $\begin{array}{c}4.620 \\
(12.11)\end{array}$ \\
\hline IT & $\begin{array}{c}\mathbf{5 . 8 1 0 * * *} \\
(1.220)\end{array}$ & $\begin{array}{c}\mathbf{6 . 0 3 2} * * * \\
(1.006)\end{array}$ & $\begin{array}{c}5.273 * * * \\
(1.249)\end{array}$ & $\begin{array}{c}\text { 71.38*** } \\
(1.843)\end{array}$ & $\begin{array}{c}75.65 * * * \\
(1.270)\end{array}$ & $\begin{array}{c}72.33^{* * *} \\
(2.041)\end{array}$ & $\begin{array}{l}-0.935 \\
(1.073)\end{array}$ & $\begin{array}{l}-0.743 \\
(1.034)\end{array}$ & $\begin{array}{c}0.477 \\
(0.956)\end{array}$ & $\begin{array}{c}-3.230^{* * *} \\
(1.182)\end{array}$ & $\begin{array}{l}-2.730^{*} \\
(1.490)\end{array}$ & $\begin{array}{c}0.541 \\
(1.393)\end{array}$ \\
\hline $\mathrm{JP}$ & $\begin{array}{c}3.623 \\
(3.786)\end{array}$ & $\begin{array}{l}-2.139 \\
(3.365)\end{array}$ & $\begin{array}{l}-0.669 \\
(3.589)\end{array}$ & $\begin{array}{c}\text { 163.4*** } \\
(5.435)\end{array}$ & $\begin{array}{c}154.8^{* * * *} \\
(5.739)\end{array}$ & $\begin{array}{c}153.7 * * * \\
(3.965)\end{array}$ & $\begin{array}{l}-1.143 \\
(4.148)\end{array}$ & $\begin{array}{c}4.052 \\
(2.904)\end{array}$ & $\begin{array}{l}-4.138 \\
(3.611)\end{array}$ & $\begin{array}{l}-1.379 \\
(3.219)\end{array}$ & $\begin{array}{c}-7.056 * * * \\
(2.300)\end{array}$ & $\begin{array}{c}-7.511 * * * \\
(2.677)\end{array}$ \\
\hline LT & $\begin{array}{c}\mathbf{2 0 . 6 6 * * *} \\
(3.179)\end{array}$ & $\begin{array}{c}\text { 26.28**** } \\
(3.615)\end{array}$ & $\begin{array}{c}23.06 * * * \\
(3.638)\end{array}$ & $\begin{array}{c}51.68 * * * \\
(4.420)\end{array}$ & $\begin{array}{c}43.65 * * * \\
(6.098)\end{array}$ & $\begin{array}{c}\text { 41.26*** } \\
(5.906)\end{array}$ & $\begin{array}{l}-4.235 \\
(2.584)\end{array}$ & $\begin{array}{c}-5.772 * * \\
(2.777)\end{array}$ & $\begin{array}{l}-2.826 \\
(3.278)\end{array}$ & $\begin{array}{l}-3.665 \\
(2.962)\end{array}$ & $\begin{array}{c}-4.930 * * \\
(2.500)\end{array}$ & $\begin{array}{l}-4.674 * \\
(2.760)\end{array}$ \\
\hline LV & $\begin{array}{c}\text { 26.85*** } \\
(4.133)\end{array}$ & $\begin{array}{c}\text { 23.81*** } \\
(2.543)\end{array}$ & $\begin{array}{c}\text { 24.16*** } \\
(3.251)\end{array}$ & $\begin{array}{c}\text { 49.51*** } \\
(4.564)\end{array}$ & $\begin{array}{c}\mathbf{5 0 . 6 1} * * * \\
(4.181)\end{array}$ & $\begin{array}{c}\text { 49.81*** } \\
(4.018)\end{array}$ & $\begin{array}{l}-4.468 * \\
(2.583)\end{array}$ & $\begin{array}{l}-0.709 \\
(1.911)\end{array}$ & $\begin{array}{l}-0.254 \\
(2.439)\end{array}$ & $\begin{array}{l}-0.117 \\
(5.287)\end{array}$ & $\begin{array}{l}-3.044 \\
(4.750)\end{array}$ & $\begin{array}{l}-2.045 \\
(3.831)\end{array}$ \\
\hline LU & $\begin{array}{l}\text { 8.154* } \\
(4.850)\end{array}$ & $\begin{array}{c}14.49 * * * \\
(2.450)\end{array}$ & $\begin{array}{c}9.790 * * * \\
(2.840)\end{array}$ & $\begin{array}{c}76.93 * * * \\
(6.697)\end{array}$ & $\begin{array}{c}\text { 65.34*** } \\
(2.897)\end{array}$ & $\begin{array}{c}\text { 61.92*** } \\
(3.905)\end{array}$ & $\begin{array}{c}1.470 \\
(2.948)\end{array}$ & $\begin{array}{c}0.685 \\
(1.565)\end{array}$ & $\begin{array}{c}2.589 \\
(2.003)\end{array}$ & $\begin{array}{l}-2.376 \\
(4.507)\end{array}$ & $\begin{array}{l}-4.918 \\
(4.448)\end{array}$ & $\begin{array}{c}4.497 \\
(5.431)\end{array}$ \\
\hline ND & $\begin{array}{l}-0.310 \\
(2.790)\end{array}$ & $\begin{array}{c}1.147 \\
(3.119)\end{array}$ & $\begin{array}{l}-3.240 \\
(2.844)\end{array}$ & $\begin{array}{c}122.9 * * * \\
(3.861)\end{array}$ & $\begin{array}{c}114.4 * * * \\
(4.853)\end{array}$ & $\begin{array}{c}\text { 98.48*** } \\
(3.698)\end{array}$ & $\begin{array}{c}6.385 * * \\
(2.674)\end{array}$ & $\begin{array}{l}4.619 * * \\
(2.160)\end{array}$ & $\begin{array}{c}\text { 7.956*** } \\
(1.567)\end{array}$ & $\begin{array}{c}-21.12 * * * \\
(4.305)\end{array}$ & $\begin{array}{c}-\mathbf{1 6 . 9 9} * * * \\
(3.411)\end{array}$ & $\begin{array}{c}-\mathbf{1 0 . 8 3} * * * \\
(2.564)\end{array}$ \\
\hline NO & $\begin{array}{c}\text { 28.96*** } \\
(6.142)\end{array}$ & $\begin{array}{c}33.26 * * * \\
(5.079)\end{array}$ & $\begin{array}{c}33.02 * * * \\
(5.024)\end{array}$ & $\begin{array}{c}36.90 * * * \\
(7.032)\end{array}$ & $\begin{array}{c}37.29 * * * \\
(6.743)\end{array}$ & $\begin{array}{c}\mathbf{1 7 . 4 6 * *} \\
(8.753)\end{array}$ & $\begin{array}{c}0.319 \\
(5.375)\end{array}$ & $\begin{array}{l}-4.024 \\
(5.109)\end{array}$ & $\begin{array}{l}-0.217 \\
(5.259)\end{array}$ & $\begin{array}{l}-2.759 \\
(5.357)\end{array}$ & $\begin{array}{l}-4.492 \\
(5.712)\end{array}$ & $\begin{array}{l}-5.090 * \\
(3.033)\end{array}$ \\
\hline PL & $\begin{array}{c}29.57 * * * \\
(3.153)\end{array}$ & $\begin{array}{c}28.23 * * * \\
(2.639)\end{array}$ & $\begin{array}{c}29.04 * * * \\
(3.110)\end{array}$ & $\begin{array}{c}22.78 * * * \\
(4.767)\end{array}$ & $\begin{array}{c}26.11^{* * *} \\
(3.486)\end{array}$ & $\begin{array}{c}24.48 * * * \\
(4.898)\end{array}$ & $\begin{array}{c}4.052 \\
(4.193)\end{array}$ & $\begin{array}{c}3.695 \\
(3.284)\end{array}$ & $\begin{array}{l}-1.277 \\
(3.863)\end{array}$ & $\begin{array}{c}2.442 \\
(5.332)\end{array}$ & $\begin{array}{l}5.425^{*} \\
(2.915)\end{array}$ & $\begin{array}{l}1.948 \\
(3.614)\end{array}$ \\
\hline $\mathrm{PT}$ & $\begin{array}{c}\mathbf{2 0 . 7 2 * * *} \\
(1.994)\end{array}$ & $\begin{array}{c}\text { 20.05*** } \\
(1.206)\end{array}$ & $\begin{array}{c}21.88 * * * \\
(1.700)\end{array}$ & $\begin{array}{c}\mathbf{4 1 . 7 1 * * *} \\
(2.207)\end{array}$ & $\begin{array}{c}\text { 38.59*** } \\
(2.703)\end{array}$ & $\begin{array}{c}33.37 * * * \\
(2.178)\end{array}$ & $\begin{array}{c}2.816 \\
(2.233)\end{array}$ & $\begin{array}{c}4.367 * * \\
(1.840)\end{array}$ & $\begin{array}{c}1.545 \\
(1.806)\end{array}$ & $\begin{array}{l}-4.368 \\
(3.713)\end{array}$ & $\begin{array}{l}-3.451 \\
(3.050)\end{array}$ & $\begin{array}{c}-4.731 * * \\
(2.135)\end{array}$ \\
\hline RO & $\begin{array}{c}\mathbf{1 0 . 8 5 * * *} \\
(2.124)\end{array}$ & $\begin{array}{c}\text { 9.692*** } \\
(3.183)\end{array}$ & $\begin{array}{c}\text { 13.09*** } \\
(3.514)\end{array}$ & $\begin{array}{c}65.54 * * * \\
(4.277)\end{array}$ & $\begin{array}{c}\text { 63.65*** } \\
(2.974)\end{array}$ & $\begin{array}{c}\mathbf{5 3 . 2 4} * * * \\
(4.076)\end{array}$ & $\begin{array}{c}1.927 \\
(2.059)\end{array}$ & $\begin{array}{l}\text { 4.391* } \\
(2.492)\end{array}$ & $\begin{array}{c}3.061 \\
(1.872)\end{array}$ & $\begin{array}{c}\mathbf{8 . 3 9 8}^{* * * *} \\
(2.709)\end{array}$ & $\begin{array}{c}\text { 7.167*** } \\
(2.578)\end{array}$ & $\begin{array}{c}3.592 \\
(3.053)\end{array}$ \\
\hline SK & $\begin{array}{c}28.57 * * * \\
(5.014)\end{array}$ & $\begin{array}{c}\text { 26.90*** } \\
(4.375)\end{array}$ & $\begin{array}{c}\text { 32.89*** } \\
(3.275)\end{array}$ & $\begin{array}{c}\mathbf{8 9 . 6 2 * * *} \\
(4.536)\end{array}$ & $\begin{array}{c}\text { 97.66**** } \\
(3.709)\end{array}$ & $\begin{array}{c}96.72 * * * \\
(3.274)\end{array}$ & $\begin{array}{c}\mathbf{- 1 1 . 9 2 * *} \\
(5.594)\end{array}$ & $\begin{array}{c}-9.115 * * \\
(4.620)\end{array}$ & $\begin{array}{c}\mathbf{- 1 0 . 6 0 * *} \\
(4.150)\end{array}$ & $\begin{array}{l}-2.647 \\
(3.709)\end{array}$ & $\begin{array}{c}-7.890 * * \\
(3.450)\end{array}$ & $\begin{array}{l}-2.996 \\
(3.358)\end{array}$ \\
\hline SI & $\begin{array}{c}0.253 \\
(1.978)\end{array}$ & $\begin{array}{c}5.254 * * * \\
(1.812)\end{array}$ & $\begin{array}{c}3.592 \\
(2.949)\end{array}$ & $\begin{array}{c}118.9 * * * \\
(3.935)\end{array}$ & $\begin{array}{c}119.4 * * * \\
(3.280)\end{array}$ & $\begin{array}{c}117.2^{* * *} \\
(3.860)\end{array}$ & $\begin{array}{c}0.988 \\
(3.102)\end{array}$ & $\begin{array}{l}-1.414 \\
(2.252)\end{array}$ & $\begin{array}{l}-0.130 \\
(3.195)\end{array}$ & $\begin{array}{c}0.725 \\
(2.886)\end{array}$ & $\begin{array}{c}\mathbf{6 . 0 3 4} * * * \\
(2.081)\end{array}$ & $\begin{array}{l}6.863^{*} \\
(3.776)\end{array}$ \\
\hline ES & $\begin{array}{c}22.70 * * * \\
(0.904)\end{array}$ & $\begin{array}{c}\text { 20.76*** } \\
(0.969)\end{array}$ & $\begin{array}{c}\mathbf{1 8 . 1 2} \text { **** } \\
(1.325)\end{array}$ & $\begin{array}{c}33.69 * * * \\
(1.367)\end{array}$ & $\begin{array}{c}\text { 26.33*** } \\
(1.004)\end{array}$ & $\begin{array}{c}23.53^{* * *} \\
(1.593)\end{array}$ & $\begin{array}{l}-1.372 \\
(1.124)\end{array}$ & $\begin{array}{c}\mathbf{1 . 7 1 4} * * \\
(0.833)\end{array}$ & $\begin{array}{l}2.383^{*} \\
(1.358)\end{array}$ & $\begin{array}{l}-1.857 \\
(2.364)\end{array}$ & $\begin{array}{c}-3.011^{* *} \\
(1.475)\end{array}$ & $\begin{array}{c}-2.818^{* *} \\
(1.398)\end{array}$ \\
\hline SE & $\begin{array}{c}\text { 28.61*** } \\
(5.083)\end{array}$ & $\begin{array}{c}30.47^{* * *} \\
(2.719)\end{array}$ & $\begin{array}{c}29.61 * * * \\
(2.774)\end{array}$ & $\begin{array}{c}\mathbf{4 8 . 1 2 * * *} \\
(5.272)\end{array}$ & $\begin{array}{c}\mathbf{4 6 . 6 7 * * *} \\
(5.055)\end{array}$ & $\begin{array}{c}\mathbf{4 7 . 8 6 * * *} \\
(2.947)\end{array}$ & $\begin{array}{c}3.954 \\
(4.217)\end{array}$ & $\begin{array}{c}2.072 \\
(3.664)\end{array}$ & $\begin{array}{l}-1.993 \\
(2.334)\end{array}$ & $\begin{array}{c}2.163 \\
(4.812)\end{array}$ & $\begin{array}{l}-2.664 \\
(3.421)\end{array}$ & $\begin{array}{l}-0.0127 \\
(3.516)\end{array}$ \\
\hline $\mathrm{CH}$ & $\begin{array}{c}\text { 19.71*** } \\
(3.371)\end{array}$ & $\begin{array}{c}19.00 * * * \\
(2.054)\end{array}$ & $\begin{array}{c}\text { 18.91**** } \\
(2.985)\end{array}$ & $\begin{array}{c}\mathbf{8 5 . 1 8 * * *} \\
(5.631)\end{array}$ & $\begin{array}{c}\text { 79.13*** } \\
(3.744)\end{array}$ & $\begin{array}{c}72.90 * * * \\
(3.209)\end{array}$ & $\begin{array}{c}0.841 \\
(1.840)\end{array}$ & $\begin{array}{l}-0.126 \\
(1.581)\end{array}$ & $\begin{array}{l}-0.809 \\
(1.958)\end{array}$ & $\begin{array}{c}-28.57 * * * \\
(2.411)\end{array}$ & $\begin{array}{c}-29.19 * * * \\
(1.830)\end{array}$ & $\begin{array}{c}-27.79 * * * \\
(2.917)\end{array}$ \\
\hline UK & $\begin{array}{l}19.44 * * \\
(8.008)\end{array}$ & $\begin{array}{c}21.82 * * * \\
(5.182)\end{array}$ & $\begin{array}{c}\text { 18.81*** } \\
(4.589)\end{array}$ & $\begin{array}{c}64.20 * * * \\
(4.069)\end{array}$ & $\begin{array}{c}\text { 64.88*** } \\
(2.553)\end{array}$ & $\begin{array}{c}\text { 69.76*** } \\
(2.083)\end{array}$ & $\begin{array}{c}7.142 \\
(7.565)\end{array}$ & $\begin{array}{c}5.506 \\
(4.195)\end{array}$ & $\begin{array}{l}6.918^{*} \\
(4.007)\end{array}$ & $\begin{array}{c}-\mathbf{4 8 . 7 9 * * *} \\
(11.47)\end{array}$ & $\begin{array}{c}-37.56 * * * \\
(10.13)\end{array}$ & $\begin{array}{c}-29.45 * * * \\
(7.542)\end{array}$ \\
\hline US & $\begin{array}{c}21.61 * * * \\
(7.033)\end{array}$ & $\begin{array}{c}\text { 18.93*** } \\
(3.842)\end{array}$ & $\begin{array}{c}12.90 * * \\
(5.326)\end{array}$ & $\begin{array}{c}42.36 * * * \\
(5.624)\end{array}$ & $\begin{array}{c}\mathbf{4 3 . 6 9} * * * * \\
(3.360)\end{array}$ & $\begin{array}{c}36.76^{* * *} \\
(3.907)\end{array}$ & $\begin{array}{c}0.489 \\
(6.349)\end{array}$ & $\begin{array}{l}\text { 6.118* } \\
(3.493)\end{array}$ & $\begin{array}{c}\text { 13.31*** } \\
(5.013)\end{array}$ & $\begin{array}{c}14.17 * * * \\
(4.822)\end{array}$ & $\begin{array}{c}\mathbf{9 . 9 6 7 * * *} \\
(3.565)\end{array}$ & $\begin{array}{c}4.574 \\
(4.906)\end{array}$ \\
\hline
\end{tabular}

All regressions controlled for age, gender, father at home, mother at home, immigrant status, second generation immigrant status, language spoken at home. Data for France on 'ability grouping' is missing. Standard errors are reported in brackets. 
Table A2: Regressions of PISA 2009 Mathematics test scores, on the socio-economic gradient, pre-primary education participation and their interaction effect Quantile regressions for 20, 50 and 80 percent quantile.

\begin{tabular}{|c|c|c|c|c|c|c|c|c|c|c|c|c|}
\hline & \multicolumn{3}{|c|}{ ESCS } & \multicolumn{3}{|c|}{ m_ESCS } & \multicolumn{3}{|c|}{ Interaction } & \multicolumn{3}{|c|}{ PRE-PRIMARY } \\
\hline & q20 & q50 & q80 & q20 & q50 & q80 & $\mathrm{q} 20$ & q50 & q80 & q20 & q50 & q80 \\
\hline AUT & $\begin{array}{c}4.221 \\
(7.274)\end{array}$ & $\begin{array}{c}6.471 \\
(8.656)\end{array}$ & $\begin{array}{c}3.830 \\
(7.735)\end{array}$ & $\begin{array}{c}\text { 105.4*** } \\
(6.246)\end{array}$ & $\begin{array}{c}\text { 115.1*** } \\
(3.097)\end{array}$ & $\begin{array}{c}110.9 * * * \\
(3.648)\end{array}$ & $\begin{array}{c}1.876 \\
(3.271)\end{array}$ & $\begin{array}{c}0.00576 \\
(4.454)\end{array}$ & $\begin{array}{c}1.031 \\
(4.046)\end{array}$ & $\begin{array}{c}\mathbf{2 5 . 7 5 * *} \\
(12.08)\end{array}$ & $\begin{array}{c}4.387 \\
(9.937)\end{array}$ & $\begin{array}{c}4.556 \\
(9.644)\end{array}$ \\
\hline BEL & $\begin{array}{l}-1.606 \\
(6.450)\end{array}$ & $\begin{array}{c}19.00 * * * \\
(6.261)\end{array}$ & $\begin{array}{l}\text { 19.66* } \\
(11.50)\end{array}$ & $\begin{array}{c}102.6 * * * \\
(2.594)\end{array}$ & $\begin{array}{c}\mathbf{9 1 . 4 8 * * *} \\
(2.037)\end{array}$ & $\begin{array}{c}\text { 81.47*** } \\
(3.026)\end{array}$ & $\begin{array}{l}\text { 8.315** } \\
(3.240)\end{array}$ & $\begin{array}{l}-2.400 \\
(3.039)\end{array}$ & $\begin{array}{l}-3.884 \\
(5.859)\end{array}$ & $\begin{array}{c}\mathbf{4 8 . 8 9 * * *} \\
(9.184)\end{array}$ & $\begin{array}{c}39.77 * * * \\
(7.778)\end{array}$ & $\begin{array}{c}39.73 * * * \\
(10.12)\end{array}$ \\
\hline BUL & $\begin{array}{c}18.60 * * * \\
(4.042)\end{array}$ & $\begin{array}{c}\text { 18.56*** } \\
(3.370)\end{array}$ & $\begin{array}{c}16.06 * * * \\
(4.938)\end{array}$ & $\begin{array}{c}\text { 77.21*** } \\
(5.198)\end{array}$ & $\begin{array}{c}\text { 72.59*** } \\
(3.929)\end{array}$ & $\begin{array}{c}\mathbf{6 9 . 0 7 * * *} \\
(4.435)\end{array}$ & $\begin{array}{c}0.404 \\
(2.415)\end{array}$ & $\begin{array}{c}1.404 \\
(2.224)\end{array}$ & $\begin{array}{c}2.518 \\
(2.027)\end{array}$ & $\begin{array}{c}8.638 \\
(7.619)\end{array}$ & $\begin{array}{l}\text { 8.592* } \\
(5.019)\end{array}$ & $\begin{array}{c}5.852 \\
(7.630)\end{array}$ \\
\hline $\mathrm{CZ}$ & $\begin{array}{c}20.47 * * * \\
(5.664)\end{array}$ & $\begin{array}{c}23.32 * * * \\
(7.881)\end{array}$ & $\begin{array}{c}14.46 \\
(11.65)\end{array}$ & $\begin{array}{c}\text { 138.0*** } \\
(4.786)\end{array}$ & $\begin{array}{c}146.7 * * * \\
(5.726)\end{array}$ & $\begin{array}{c}134.9 * * * \\
(4.550)\end{array}$ & $\begin{array}{l}-1.412 \\
(3.105)\end{array}$ & $\begin{array}{l}-3.938 \\
(3.384)\end{array}$ & $\begin{array}{l}0.0373 \\
(5.960)\end{array}$ & $\begin{array}{c}22.51 * * * \\
(6.684)\end{array}$ & $\begin{array}{c}19.85 * * * \\
(6.340)\end{array}$ & $\begin{array}{c}12.63 \\
(14.88)\end{array}$ \\
\hline DK & $\begin{array}{l}\text { 13.04** } \\
(5.649)\end{array}$ & $\begin{array}{c}18.80 * * * \\
(4.820)\end{array}$ & $\begin{array}{c}15.66 * * * \\
(4.650)\end{array}$ & $\begin{array}{c}\text { 31.88*** } \\
(6.183)\end{array}$ & $\begin{array}{c}26.88 * * * \\
(4.669)\end{array}$ & $\begin{array}{c}\mathbf{2 6 . 9 5 * * *} \\
(3.233)\end{array}$ & $\begin{array}{l}\text { 6.122* } \\
(3.628)\end{array}$ & $\begin{array}{l}5.640 * \\
(3.230)\end{array}$ & $\begin{array}{l}6.557^{* *} \\
(2.773)\end{array}$ & $\begin{array}{c}36.31 * * * \\
(10.30)\end{array}$ & $\begin{array}{c}35.30 * * * \\
(9.848)\end{array}$ & $\begin{array}{c}33.73 * * \\
(13.19)\end{array}$ \\
\hline $\mathrm{EE}$ & $\begin{array}{c}19.23 * * * \\
(6.230)\end{array}$ & $\begin{array}{c}15.14 * * * \\
(4.935)\end{array}$ & $\begin{array}{c}\text { 14.26*** } \\
(4.233)\end{array}$ & $\begin{array}{c}\mathbf{5 5 . 7 9}^{* * *} \\
(6.078)\end{array}$ & $\begin{array}{c}\mathbf{4 8 . 8 0}^{* * * *} \\
(4.155)\end{array}$ & $\begin{array}{c}\text { 47.52*** } \\
(5.457)\end{array}$ & $\begin{array}{l}-0.862 \\
(3.454)\end{array}$ & $\begin{array}{c}2.194 \\
(2.767)\end{array}$ & $\begin{array}{c}1.826 \\
(2.967)\end{array}$ & $\begin{array}{l}-5.639 \\
(5.719)\end{array}$ & $\begin{array}{c}-\mathbf{- 1 2 . 2 * * *} \\
(3.596)\end{array}$ & $\begin{array}{c}-20.4 * * * \\
(4.958)\end{array}$ \\
\hline FI & $\begin{array}{c}22.48 * * * \\
(7.695)\end{array}$ & $\begin{array}{c}22.62 * * * \\
(3.530)\end{array}$ & $\begin{array}{c}21.06 * * * \\
(3.619)\end{array}$ & $\begin{array}{l}\text { 10.85* } \\
(6.406)\end{array}$ & $\begin{array}{c}5.057 \\
(3.853)\end{array}$ & $\begin{array}{c}11.29 * * * \\
(4.206)\end{array}$ & $\begin{array}{l}-0.146 \\
(3.079)\end{array}$ & $\begin{array}{c}1.631 \\
(2.128)\end{array}$ & $\begin{array}{c}1.798 \\
(1.951)\end{array}$ & $\begin{array}{c}2.660 \\
(9.038)\end{array}$ & $\begin{array}{l}-5.437 \\
(5.686)\end{array}$ & $\begin{array}{l}-1.025 \\
(6.551)\end{array}$ \\
\hline FR & $\begin{array}{l}-1.379 \\
(11.94)\end{array}$ & $\begin{array}{l}-4.328 \\
(7.154)\end{array}$ & $\begin{array}{l}-3.796 \\
(7.042)\end{array}$ & $\begin{array}{c}\text { 114.6*** } \\
(5.755)\end{array}$ & $\begin{array}{c}111.2 * * * \\
(4.123)\end{array}$ & $\begin{array}{c}\text { 109.8*** } \\
(4.941)\end{array}$ & $\begin{array}{c}6.774 \\
(5.735)\end{array}$ & $\begin{array}{c}9.523^{* *} \\
(3.877)\end{array}$ & $\begin{array}{l}\text { 7.890** } \\
(3.808)\end{array}$ & $\begin{array}{c}11.46 \\
(10.64)\end{array}$ & $\begin{array}{l}17.38^{*} \\
\text { (9.209) }\end{array}$ & $\begin{array}{c}10.73 \\
(8.981)\end{array}$ \\
\hline GE & $\begin{array}{l}31.11 \text { ** } \\
(15.56)\end{array}$ & $\begin{array}{c}24.49 * * * \\
(7.831)\end{array}$ & $\begin{array}{c}21.93 \\
(19.02)\end{array}$ & $\begin{array}{c}107.2 * * * \\
(5.057)\end{array}$ & $\begin{array}{c}\mathbf{9 6 . 7 8 * * *} \\
(3.618)\end{array}$ & $\begin{array}{c}\text { 91.82*** } \\
(4.117)\end{array}$ & $\begin{array}{l}-8.889 \\
(8.232)\end{array}$ & $\begin{array}{l}-4.366 \\
(4.238)\end{array}$ & $\begin{array}{l}-2.272 \\
(9.813)\end{array}$ & $\begin{array}{l}\text { 49.28** } \\
(20.51)\end{array}$ & $\begin{array}{c}\mathbf{5 6 . 9 9 * * *} \\
(9.095)\end{array}$ & $\begin{array}{c}\mathbf{6 5 . 6 1 * * *} \\
(19.53)\end{array}$ \\
\hline GR & $\begin{array}{c}\mathbf{8 . 7 0 7 * * *} \\
(2.555)\end{array}$ & $\begin{array}{c}\mathbf{1 4 . 1 0 * * *} \\
(4.705)\end{array}$ & $\begin{array}{c}22.16 * * * \\
(4.553)\end{array}$ & $\begin{array}{c}\text { 51.51*** } \\
(3.179)\end{array}$ & $\begin{array}{c}\mathbf{4 3 . 8 3} * * * \\
(3.957)\end{array}$ & $\begin{array}{c}37.35 * * * \\
(5.072)\end{array}$ & $\begin{array}{c}2.629 \\
(1.833)\end{array}$ & $\begin{array}{c}2.286 \\
(2.815)\end{array}$ & $\begin{array}{l}-0.199 \\
(2.371)\end{array}$ & $\begin{array}{l}-2.309 \\
(4.590)\end{array}$ & $\begin{array}{c}9.382 \\
(6.639)\end{array}$ & $\begin{array}{l}\text { 11.20* } \\
\text { (6.725) }\end{array}$ \\
\hline $\mathrm{HU}$ & $\begin{array}{l}-1.204 \\
(10.75)\end{array}$ & $\begin{array}{c}6.010 \\
(10.09)\end{array}$ & $\begin{array}{c}5.137 \\
(9.791)\end{array}$ & $\begin{array}{c}\text { 89.33*** } \\
(3.791)\end{array}$ & $\begin{array}{c}\text { 88.68*** } \\
(2.744)\end{array}$ & $\begin{array}{c}\text { 87.29*** } \\
(3.541)\end{array}$ & $\begin{array}{c}3.370 \\
(5.193)\end{array}$ & $\begin{array}{c}1.207 \\
(5.011)\end{array}$ & $\begin{array}{c}3.278 \\
(4.713)\end{array}$ & $\begin{array}{c}19.18 \\
(14.17)\end{array}$ & $\begin{array}{c}16.84 \\
(15.23)\end{array}$ & $\begin{array}{c}18.90 \\
(17.28)\end{array}$ \\
\hline IE & $\begin{array}{c}31.12 * * * \\
(4.437)\end{array}$ & $\begin{array}{c}29.59 * * * \\
(2.856)\end{array}$ & $\begin{array}{c}29.63 * * * \\
(4.558)\end{array}$ & $\begin{array}{c}32.73 * * * \\
(6.564)\end{array}$ & $\begin{array}{c}23.72 * * * \\
(4.329)\end{array}$ & $\begin{array}{c}24.15 * * * \\
(5.212)\end{array}$ & $\begin{array}{l}-1.328 \\
(2.555)\end{array}$ & $\begin{array}{l}-0.758 \\
(1.724)\end{array}$ & $\begin{array}{l}-1.265 \\
(3.138)\end{array}$ & $\begin{array}{l}-6.903 \\
(4.651)\end{array}$ & $\begin{array}{l}-5.797 \\
(4.414)\end{array}$ & $\begin{array}{l}-5.020 \\
(4.724)\end{array}$ \\
\hline IT & $\begin{array}{c}3.444 \\
(2.837)\end{array}$ & $\begin{array}{c}\text { 8.037*** } \\
(2.877)\end{array}$ & $\begin{array}{c}\text { 8.392*** } \\
(3.102)\end{array}$ & $\begin{array}{c}\text { 71.13*** } \\
(1.439)\end{array}$ & $\begin{array}{c}\mathbf{7 4 . 8 1}^{* * * *} \\
(1.864)\end{array}$ & $\begin{array}{c}\text { 72.30*** } \\
(1.267)\end{array}$ & $\begin{array}{c}0.805 \\
(1.636)\end{array}$ & $\begin{array}{l}-1.413 \\
(1.385)\end{array}$ & $\begin{array}{l}-1.484 \\
(1.620)\end{array}$ & $\begin{array}{c}33.47 * * * \\
(3.476)\end{array}$ & $\begin{array}{c}32.69 * * * \\
(2.332)\end{array}$ & $\begin{array}{c}27.17 * * * \\
(3.273)\end{array}$ \\
\hline JP & $\begin{array}{c}33.47 \\
(21.51)\end{array}$ & $\begin{array}{c}12.86 \\
(14.90)\end{array}$ & $\begin{array}{c}1.480 \\
(15.59)\end{array}$ & $\begin{array}{c}\text { 164.2*** } \\
(6.317)\end{array}$ & $\begin{array}{c}\text { 153.5*** } \\
(3.249)\end{array}$ & $\begin{array}{c}\text { 151.0*** } \\
(4.358)\end{array}$ & $\begin{array}{l}-15.67 \\
(11.50)\end{array}$ & $\begin{array}{l}-6.193 \\
(7.210)\end{array}$ & $\begin{array}{l}-2.621 \\
(7.857)\end{array}$ & $\begin{array}{c}3.472 \\
(21.37)\end{array}$ & $\begin{array}{c}6.931 \\
(14.72)\end{array}$ & $\begin{array}{c}\mathbf{1 9 . 4 8 * *} \\
(8.914)\end{array}$ \\
\hline LT & $\begin{array}{c}12.50 * * * \\
(3.549)\end{array}$ & $\begin{array}{c}\text { 26.81*** } \\
(3.533)\end{array}$ & $\begin{array}{c}26.25 * * * \\
(4.705)\end{array}$ & $\begin{array}{c}52.72 * * * \\
(4.335)\end{array}$ & $\begin{array}{c}\text { 43.17*** } \\
(3.638)\end{array}$ & $\begin{array}{c}\text { 41.02*** } \\
(3.938)\end{array}$ & $\begin{array}{l}3.372 * \\
(1.720)\end{array}$ & $\begin{array}{l}-2.486 \\
(2.160)\end{array}$ & $\begin{array}{l}-3.057 \\
(2.971)\end{array}$ & $\begin{array}{l}-3.901 \\
(3.666)\end{array}$ & $\begin{array}{l}-4.004 \\
(3.378)\end{array}$ & $\begin{array}{c}-9.530 * * \\
(4.353)\end{array}$ \\
\hline LV & $\begin{array}{c}22.56 * * * \\
(2.578)\end{array}$ & $\begin{array}{c}\text { 26.18*** } \\
(3.141)\end{array}$ & $\begin{array}{c}24.27 * * * \\
(3.306)\end{array}$ & $\begin{array}{c}\mathbf{5 1 . 7 3 * * *} \\
(3.148)\end{array}$ & $\begin{array}{c}\mathbf{5 0 . 4 9 * * *} \\
(4.580)\end{array}$ & $\begin{array}{c}52.74 * * * \\
(4.448)\end{array}$ & $\begin{array}{c}0.218 \\
(2.389)\end{array}$ & $\begin{array}{l}-2.095 \\
(2.071)\end{array}$ & $\begin{array}{c}0.153 \\
(2.265)\end{array}$ & $\begin{array}{l}-4.936 \\
(3.468)\end{array}$ & $\begin{array}{l}-4.865 \\
(4.961)\end{array}$ & $\begin{array}{c}-12.4 * * * \\
(4.260)\end{array}$ \\
\hline LU & $\begin{array}{l}15.86 * * \\
(7.357)\end{array}$ & $\begin{array}{l}\mathbf{1 6 . 2 9 * *} \\
(6.488)\end{array}$ & $\begin{array}{l}\text { 15.89* } \\
(8.387)\end{array}$ & $\begin{array}{c}\text { 75.68*** } \\
(2.869)\end{array}$ & $\begin{array}{c}\mathbf{6 6 . 4 9} * * * \\
(2.931)\end{array}$ & $\begin{array}{c}\mathbf{5 8 . 6 5 * * *} \\
(3.550)\end{array}$ & $\begin{array}{l}-2.978 \\
(3.591)\end{array}$ & $\begin{array}{l}-0.658 \\
(3.640)\end{array}$ & $\begin{array}{l}-1.477 \\
(4.920)\end{array}$ & $\begin{array}{c}4.282 \\
(10.24)\end{array}$ & $\begin{array}{l}7.090 \\
(9.074)\end{array}$ & $\begin{array}{c}10.17 \\
(11.16)\end{array}$ \\
\hline ND & $\begin{array}{l}\text { 15.06* } \\
(8.706)\end{array}$ & $\begin{array}{c}6.096 \\
(8.629)\end{array}$ & $\begin{array}{c}3.943 \\
(9.273)\end{array}$ & $\begin{array}{c}124.9 * * * \\
(2.868)\end{array}$ & $\begin{array}{c}\text { 115.5*** } \\
(4.392)\end{array}$ & $\begin{array}{c}\text { 96.58*** } \\
(4.300)\end{array}$ & $\begin{array}{l}-3.475 \\
(4.289)\end{array}$ & $\begin{array}{l}-0.133 \\
(4.593)\end{array}$ & $\begin{array}{c}2.008 \\
(4.672)\end{array}$ & $\begin{array}{c}1.194 \\
(8.362)\end{array}$ & $\begin{array}{c}1.569 \\
(6.664)\end{array}$ & $\begin{array}{l}-9.727 \\
(10.14)\end{array}$ \\
\hline NO & $\begin{array}{l}\mathbf{1 5 . 4 4 * *} \\
(6.303)\end{array}$ & $\begin{array}{l}14.21 * * \\
(5.888)\end{array}$ & $\begin{array}{c}20.46 * * * \\
(4.823)\end{array}$ & $\begin{array}{c}33.83 * * * \\
(8.204)\end{array}$ & $\begin{array}{c}33.17 * * * \\
(4.934)\end{array}$ & $\begin{array}{l}\text { 16.24** } \\
(6.429)\end{array}$ & $\begin{array}{l}\text { 8.356** } \\
(3.979)\end{array}$ & $\begin{array}{c}9.360 * * * \\
(3.111)\end{array}$ & $\begin{array}{l}\text { 7.718** } \\
(3.127)\end{array}$ & $\begin{array}{l}-4.972 \\
(6.837)\end{array}$ & $\begin{array}{c}3.661 \\
(5.154)\end{array}$ & $\begin{array}{l}12.75 * * \\
(5.569)\end{array}$ \\
\hline PL & $\begin{array}{c}\text { 30.05*** } \\
(3.294)\end{array}$ & $\begin{array}{c}22.93 * * * \\
(4.350)\end{array}$ & $\begin{array}{c}31.22 * * * \\
(4.999)\end{array}$ & $\begin{array}{c}24.16 * * * \\
(2.814)\end{array}$ & $\begin{array}{c}29.19 * * * \\
(4.087)\end{array}$ & $\begin{array}{c}25.00 * * * \\
(3.219)\end{array}$ & $\begin{array}{c}0.768 \\
(2.003)\end{array}$ & $\begin{array}{c}5.321 * * \\
(2.525)\end{array}$ & $\begin{array}{l}-1.869 \\
(3.125)\end{array}$ & $\begin{array}{c}16.73 \\
(13.57)\end{array}$ & $\begin{array}{c}18.98 \\
(13.56)\end{array}$ & $\begin{array}{c}6.196 \\
(13.40)\end{array}$ \\
\hline PT & $\begin{array}{c}14.25 * * * \\
(4.523)\end{array}$ & $\begin{array}{c}\text { 18.31*** } \\
(2.874)\end{array}$ & $\begin{array}{c}22.53 * * * \\
(4.652)\end{array}$ & $\begin{array}{c}\mathbf{4 2 . 4 6 * * *} \\
(2.346)\end{array}$ & $\begin{array}{c}38.92 * * * \\
(2.103)\end{array}$ & $\begin{array}{c}34.91 * * * \\
(2.215)\end{array}$ & $\begin{array}{l}\text { 4.692* } \\
(2.399)\end{array}$ & $\begin{array}{c}2.054 \\
(1.753)\end{array}$ & $\begin{array}{l}-0.656 \\
(2.533)\end{array}$ & $\begin{array}{l}12.74 * * \\
(5.481)\end{array}$ & $\begin{array}{l}\text { 8.286* } \\
(4.644)\end{array}$ & $\begin{array}{c}4.396 \\
(5.198)\end{array}$ \\
\hline RO & $\begin{array}{c}6.133 \\
(10.10)\end{array}$ & $\begin{array}{c}9.461 \\
(7.895)\end{array}$ & $\begin{array}{c}6.059 \\
(7.335)\end{array}$ & $\begin{array}{c}\mathbf{6 7 . 6 6 * * *} \\
(4.257)\end{array}$ & $\begin{array}{c}\text { 65.60*** } \\
(3.253)\end{array}$ & $\begin{array}{c}\mathbf{5 4 . 4 8 * * *} \\
(3.783)\end{array}$ & $\begin{array}{c}3.014 \\
(5.100)\end{array}$ & $\begin{array}{c}2.704 \\
(3.759)\end{array}$ & $\begin{array}{c}5.182 \\
(3.973)\end{array}$ & $\begin{array}{c}16.77 \\
(10.51)\end{array}$ & $\begin{array}{c}5.912 \\
(10.45)\end{array}$ & $\begin{array}{c}9.699 \\
(10.86)\end{array}$ \\
\hline SK & $\begin{array}{c}31.61 * * * \\
(4.596)\end{array}$ & $\begin{array}{c}22.72 * * * \\
(8.705)\end{array}$ & $\begin{array}{c}\text { 38.94*** } \\
(9.221)\end{array}$ & $\begin{array}{c}\mathbf{8 7 . 8 3} * * * \\
(5.499)\end{array}$ & $\begin{array}{c}\mathbf{9 8 . 8 8 * * *} \\
(4.622)\end{array}$ & $\begin{array}{c}\text { 94.94*** } \\
(4.579)\end{array}$ & $\begin{array}{l}-7.60 * * \\
(3.141)\end{array}$ & $\begin{array}{l}-2.315 \\
(4.232)\end{array}$ & $\begin{array}{l}-\mathbf{8 . 4 4 8 *} \\
(4.399)\end{array}$ & $\begin{array}{c}6.429 \\
(7.826)\end{array}$ & $\begin{array}{c}16.20 \\
(10.81)\end{array}$ & $\begin{array}{l}-0.864 \\
(10.66)\end{array}$ \\
\hline SI & $\begin{array}{l}-0.714 \\
(2.272)\end{array}$ & $\begin{array}{l}1.100 \\
(2.752)\end{array}$ & $\begin{array}{c}3.208 \\
(6.062)\end{array}$ & $\begin{array}{c}\mathbf{1 2 0 . 3} * * * \\
(3.233)\end{array}$ & $\begin{array}{c}\text { 120.1*** } \\
(3.387)\end{array}$ & $\begin{array}{c}\text { 118.7*** } \\
(3.416)\end{array}$ & $\begin{array}{c}1.110 \\
(1.713)\end{array}$ & $\begin{array}{c}2.316 \\
(1.459)\end{array}$ & $\begin{array}{c}0.183 \\
(3.050)\end{array}$ & $\begin{array}{l}-3.570 \\
(3.891)\end{array}$ & $\begin{array}{l}-0.831 \\
(3.186)\end{array}$ & $\begin{array}{l}-2.204 \\
(5.772)\end{array}$ \\
\hline ES & $\begin{array}{c}28.48 * * * \\
(3.062)\end{array}$ & $\begin{array}{c}30.50 * * * \\
(3.006)\end{array}$ & $\begin{array}{c}\text { 28.58*** } \\
(3.069)\end{array}$ & $\begin{array}{c}\text { 32.31*** } \\
(1.844)\end{array}$ & $\begin{array}{c}\mathbf{2 6 . 3 5} * * * \\
(1.502)\end{array}$ & $\begin{array}{c}23.07 * * * \\
(1.362)\end{array}$ & $\begin{array}{l}-3.63^{* *} \\
(1.416)\end{array}$ & $\begin{array}{c}4.905 * * * \\
(1.484)\end{array}$ & $\begin{array}{c}5.049 * * * \\
(1.757)\end{array}$ & $\begin{array}{c}\text { 12.61*** } \\
(4.023)\end{array}$ & $\begin{array}{c}1.430 \\
(4.428)\end{array}$ & $\begin{array}{c}2.117 \\
(3.394)\end{array}$ \\
\hline SE & $\begin{array}{c}29.82^{* * * *} \\
(6.479)\end{array}$ & $\begin{array}{c}\text { 27.54*** } \\
(6.510)\end{array}$ & $\begin{array}{c}25.40 * * * \\
(6.100)\end{array}$ & $\begin{array}{c}\text { 45.72*** } \\
(5.351)\end{array}$ & $\begin{array}{c}\text { 46.12*** } \\
(6.491)\end{array}$ & $\begin{array}{c}\text { 48.10*** } \\
(5.390)\end{array}$ & $\begin{array}{c}0.797 \\
(3.509)\end{array}$ & $\begin{array}{c}2.517 \\
(3.009)\end{array}$ & $\begin{array}{c}0.668 \\
(3.224)\end{array}$ & $\begin{array}{c}\text { 31.21*** } \\
(6.881)\end{array}$ & $\begin{array}{c}24.70^{* * * *} \\
(8.738)\end{array}$ & $\begin{array}{c}24.42 * * * \\
(6.488)\end{array}$ \\
\hline $\mathrm{CH}$ & $\begin{array}{c}24.14 * * * \\
(4.602)\end{array}$ & $\begin{array}{c}\text { 17.48*** } \\
(3.967)\end{array}$ & $\begin{array}{c}17.13 * * * \\
(3.135)\end{array}$ & $\begin{array}{c}90.20 * * * \\
(3.542)\end{array}$ & $\begin{array}{c}\text { 90.13*** } \\
(3.257)\end{array}$ & $\begin{array}{c}\text { 87.15*** } \\
(2.018)\end{array}$ & $\begin{array}{l}-1.701 \\
(2.786)\end{array}$ & $\begin{array}{c}0.295 \\
(2.217)\end{array}$ & $\begin{array}{c}-0.311 \\
(1.780)\end{array}$ & $\begin{array}{c}31.03 * * * \\
(7.115)\end{array}$ & $\begin{array}{c}\mathbf{4 1 . 5 6 * * *} \\
(12.24)\end{array}$ & $\begin{array}{c}\text { 42.78*** } \\
(8.038)\end{array}$ \\
\hline UK & $\begin{array}{c}17.87 * * * \\
(4.121)\end{array}$ & $\begin{array}{c}23.15 * * * \\
(3.266)\end{array}$ & $\begin{array}{c}\text { 18.68*** } \\
(3.216)\end{array}$ & $\begin{array}{c}\text { 63.25*** } \\
(2.836)\end{array}$ & $\begin{array}{c}\text { 64.73*** } \\
(2.395)\end{array}$ & $\begin{array}{c}\text { 70.57*** } \\
(3.189)\end{array}$ & $\begin{array}{l}5.926 * * \\
(2.498)\end{array}$ & $\begin{array}{c}2.832 \\
(1.812)\end{array}$ & $\begin{array}{c}3.978 * * \\
(1.937)\end{array}$ & $\begin{array}{c}18.24 * * * \\
(5.057)\end{array}$ & $\begin{array}{c}19.72 * * * \\
(5.627)\end{array}$ & $\begin{array}{c}18.30 * * * \\
(4.707)\end{array}$ \\
\hline US & $\begin{array}{c}\mathbf{1 8 . 4 9 * *} \\
(9.167)\end{array}$ & $\begin{array}{c}\text { 27.18*** } \\
(5.035)\end{array}$ & $\begin{array}{c}28.37 * * * \\
(6.700)\end{array}$ & $\begin{array}{c}\text { 43.98*** } \\
(4.592)\end{array}$ & $\begin{array}{c}\text { 46.00*** } \\
(3.639)\end{array}$ & $\begin{array}{c}40.82 * * * \\
(4.308)\end{array}$ & $\begin{array}{c}1.919 \\
(5.421)\end{array}$ & $\begin{array}{l}-1.883 \\
(2.905)\end{array}$ & $\begin{array}{l}-2.062 \\
(3.668)\end{array}$ & $\begin{array}{c}25.34 \\
(19.44)\end{array}$ & $\begin{array}{c}10.01 \\
(10.58)\end{array}$ & $\begin{array}{c}-0.724 \\
(18.26)\end{array}$ \\
\hline
\end{tabular}

All regressions controlled for age, gender, father at home, mother at home, immigrant status, second generation immigrant status, language spoken at home. Standard errors are reported in brackets. 
Table A3: Regressions of PISA 2009 Mathematics test scores, on the socio-economic gradient, ability grouping and their interaction. Ordinary Least Squares Regression

\begin{tabular}{|c|c|c|c|c|}
\hline & ESCS & m_ESCS & Interaction & ABGROUP \\
\hline \multirow[t]{2}{*}{ AT } & $5.377^{* * *}$ & 93.12*** & $9.627 * * *$ & $-30.91 * * *$ \\
\hline & $(1.725)$ & (3.091) & $(2.168)$ & $(2.246)$ \\
\hline \multirow[t]{2}{*}{$\mathrm{BE}$} & $12.87 * * *$ & $95.31 * * *$ & $6.240 * * *$ & $15.33^{* * *}$ \\
\hline & $(1.446)$ & $(2.270)$ & $(1.349)$ & (1.899) \\
\hline BG & 21.39**** & 79.67*** & $\begin{array}{l}1.615 \\
(1.696)\end{array}$ & $\begin{array}{c}2.035 \\
(2.494)\end{array}$ \\
\hline \multirow[t]{2}{*}{$\mathrm{CZ}$} & 21.79*** & $137.9 * * *$ & 0.615 & $-4.879 * *$ \\
\hline & $(2.718)$ & $(3.201)$ & (2.778) & $(2.326)$ \\
\hline $\mathrm{DE}$ & $\begin{array}{c}\text { 15.31**** } \\
(1.985)\end{array}$ & $\begin{array}{c}\text { 108.8*** } \\
(3.569)\end{array}$ & $\begin{array}{c}2.626 \\
(2.116)\end{array}$ & $\begin{array}{c}-\mathbf{1 9 . 5 5 * * *} \\
(2.755)\end{array}$ \\
\hline DK & $\begin{array}{c}\mathbf{2 8 . 2 5} * * * \\
(1.745)\end{array}$ & $\begin{array}{c}\text { 31.29*** } \\
(3.075)\end{array}$ & $\begin{array}{l}-1.456 \\
(1.987)\end{array}$ & $\begin{array}{c}-\mathbf{6 . 5 8 9 * * *} \\
(2.251)\end{array}$ \\
\hline $\mathrm{EE}$ & $\begin{array}{c}19.17^{* * *} \\
(2.173)\end{array}$ & $\begin{array}{c}\mathbf{4 7 . 8 8 * * *} \\
(3.740)\end{array}$ & $\begin{array}{c}0.860 \\
(2.136)\end{array}$ & $\begin{array}{c}0.655 \\
(2.390)\end{array}$ \\
\hline FI & $\begin{array}{c}23.54 * * * \\
(2.185)\end{array}$ & $\begin{array}{c}\mathbf{8 . 1 4 4} * * \\
(3.829)\end{array}$ & $\begin{array}{c}0.837 \\
(2.569)\end{array}$ & $\begin{array}{l}-1.924 \\
(2.445)\end{array}$ \\
\hline GR & $\begin{array}{c}\mathbf{1 8 . 1 9 * * *} \\
(1.399)\end{array}$ & $\begin{array}{c}\text { 45.57*** } \\
(2.675)\end{array}$ & $\begin{array}{c}2.394 \\
(2.986)\end{array}$ & $\begin{array}{c}1.486 \\
(3.367)\end{array}$ \\
\hline HU & $\begin{array}{c}\mathbf{1 6}^{\left(1.98^{* * *}\right.} \\
(1.953)\end{array}$ & $\begin{array}{c}\text { 88.04**** } \\
(2.167)\end{array}$ & $\begin{array}{c}-5.119 * * \\
(2.012)\end{array}$ & $\begin{array}{l}-3.953 * \\
(2.161)\end{array}$ \\
\hline IE & $\begin{array}{c}27.87 * * * \\
(5.446)\end{array}$ & $\begin{array}{c}31.23 * * * \\
(3.786)\end{array}$ & $\begin{array}{l}-0.143 \\
(4.925)\end{array}$ & $\begin{array}{l}-0.599 \\
(7.707)\end{array}$ \\
\hline IT & $\begin{array}{c}\mathbf{8 . 0 4 2 * * *} \\
(0.746)\end{array}$ & $\begin{array}{c}\text { 71.54**** } \\
(1.147)\end{array}$ & $\begin{array}{l}-0.420 \\
(0.719)\end{array}$ & $\begin{array}{l}-1.795 * \\
(0.977)\end{array}$ \\
\hline JP & $\begin{array}{c}\text { 6.294**** } \\
(2.326)\end{array}$ & $\begin{array}{c}156.3 * * * \\
(3.234)\end{array}$ & $\begin{array}{l}-1.685 \\
(2.227)\end{array}$ & $\begin{array}{c}-4.995 * * \\
(2.071)\end{array}$ \\
\hline LT & $\begin{array}{c}27.05 * * * \\
(2.381)\end{array}$ & $\begin{array}{c}52.07 * * * \\
(2.832)\end{array}$ & $\begin{array}{l}-2.450 \\
(2.072)\end{array}$ & $\begin{array}{l}-0.805 \\
(2.837)\end{array}$ \\
\hline LV & $\begin{array}{c}\mathbf{2 4 . 1 3 * * *} \\
(1.892)\end{array}$ & $\begin{array}{c}\mathbf{4 6 . 0 8 * * *} \\
(3.153)\end{array}$ & $\begin{array}{l}-2.858 \\
(1.955)\end{array}$ & $\begin{array}{c}-5.164 * * \\
(2.294)\end{array}$ \\
\hline $\mathrm{LU}$ & $\begin{array}{c}11.47 * * * \\
(2.252)\end{array}$ & $\begin{array}{c}\text { 68.74*** } \\
(3.087)\end{array}$ & $\begin{array}{c}1.638 \\
(1.419)\end{array}$ & $\begin{array}{c}-2.825 \\
(3.091)\end{array}$ \\
\hline $\mathrm{NE}$ & $\begin{array}{l}\mathbf{4 . 2 4 8}^{*} \\
(2.351)\end{array}$ & $\begin{array}{c}112.0 * * * \\
(2.945)\end{array}$ & $\begin{array}{c}\mathbf{6 . 3 1 9 * * *} \\
(1.535)\end{array}$ & $\begin{array}{c}-\mathbf{1 8 . 1 9 * * *} \\
(2.650)\end{array}$ \\
\hline $\mathrm{NO}$ & $\begin{array}{c}31.04 * * * \\
(2.930)\end{array}$ & $\begin{array}{c}\mathbf{2 8 . 5 1} * * * \\
(5.040)\end{array}$ & $\begin{array}{c}0.384 \\
(3.012)\end{array}$ & $\begin{array}{c}-4.656 \\
(3.181)\end{array}$ \\
\hline $\mathrm{PO}$ & $\begin{array}{c}\mathbf{2 8 . 4 9} * * * \\
(1.924)\end{array}$ & $\begin{array}{c}23.58 * * * \\
(3.009)\end{array}$ & $\begin{array}{c}3.588 \\
(2.323)\end{array}$ & $\begin{array}{c}3.697 \\
(2.695)\end{array}$ \\
\hline PT & $\begin{array}{c}21.78 * * * \\
(1.178)\end{array}$ & $\begin{array}{c}\text { 38.31*** } \\
(1.987)\end{array}$ & $\begin{array}{l}2.599 * \\
(1.434)\end{array}$ & $\begin{array}{c}-5.058 * * \\
(2.297)\end{array}$ \\
\hline $\mathrm{RO}$ & $\begin{array}{c}12.09 * * * \\
(2.043)\end{array}$ & $\begin{array}{c}\mathbf{6 0 . 5 4} * * * \\
(2.667)\end{array}$ & $\begin{array}{l}2.980 * \\
(1.578)\end{array}$ & $\begin{array}{c}5.387 * * \\
(2.553)\end{array}$ \\
\hline SK & $\begin{array}{c}32.55 * * * \\
(2.767)\end{array}$ & $\begin{array}{c}92.63 * * * \\
(3.322)\end{array}$ & $\begin{array}{c}-\mathbf{9 . 0 6 8} * * * \\
(2.713)\end{array}$ & $\begin{array}{c}-5.693 * * \\
(2.718)\end{array}$ \\
\hline SI & $\begin{array}{c}\mathbf{9 . 0 1 2} * * * \\
(1.710)\end{array}$ & $\begin{array}{c}120.2 * * * \\
(2.587)\end{array}$ & $\begin{array}{c}0.794 \\
(1.946)\end{array}$ & $\begin{array}{l}\text { 3.669* } \\
(1.969)\end{array}$ \\
\hline ES & 21.18*** & 28.91*** & 1.274 & $-3.026 * * *$ \\
\hline & $\begin{array}{c}(0.781) \\
32.81^{* * * *}\end{array}$ & $\begin{array}{c}(1.162) \\
\mathbf{4 7 . 2 2 * * *}\end{array}$ & $\begin{array}{c}(0.855) \\
1.065\end{array}$ & $\begin{array}{c}(1.106) \\
2.108\end{array}$ \\
\hline $\mathrm{SE}$ & $(2.742)$ & $(4.254)$ & (2.664) & (3.170) \\
\hline $\mathrm{CH}$ & $22.03^{* * *}$ & $79.10 * * *$ & -0.118 & $-27.01 * * *$ \\
\hline \multirow[t]{2}{*}{ UK } & $\begin{array}{c}(1.900) \\
\mathbf{2 3 . 5 4 * * *}\end{array}$ & $\begin{array}{c}(2.673) \\
\mathbf{6 6 . 8 4} * * *\end{array}$ & $\begin{array}{c}(1.279) \\
5.324\end{array}$ & $\begin{array}{c}(2.292) \\
-38.60 * * *\end{array}$ \\
\hline & $\begin{array}{c}23.54 \\
(3.598)\end{array}$ & $(2.300)$ & $\begin{array}{c}5.324 \\
(3.256)\end{array}$ & $\begin{array}{c}-38.60 \\
(6.626)\end{array}$ \\
\hline \multirow[t]{2}{*}{ US } & $19.41 * * *$ & $42.42 * * *$ & $5.823^{*}$ & $8.816 * *$ \\
\hline & (3.640) & $(2.747)$ & (3.445) & (3.783) \\
\hline
\end{tabular}

All regressions controlled for age, gender, father at home, mother at home, immigrant status, second generation immigrant status, language spoken at home. Data for France on 'ability grouping' is missing. Standard errors are reported in brackets. 
Table A3: Regressions of PISA 2009 Mathematics test scores, on the socio-economic gradient, pre-primary education and their interaction. Ordinary Least Squares Regression

\begin{tabular}{|c|c|c|c|c|}
\hline & ESCS & m_ESCS & Interaction & PRE-PRIMARY \\
\hline \multirow[t]{2}{*}{ AT } & $10.34 *$ & $110.0^{* * * *}$ & 0.0678 & 7.507 \\
\hline & (5.904) & (2.945) & (3.111) & (8.019) \\
\hline \multirow[t]{2}{*}{$\mathrm{BE}$} & $13.66 * *$ & $93.13^{* * *}$ & 1.414 & $41.67 * * *$ \\
\hline & (5.753) & $(2.290)$ & (2.940) & $(6.722)$ \\
\hline \multirow[t]{2}{*}{ BG } & $20.14^{* * *}$ & 78.98*** & 0.962 & $10.20^{* *}$ \\
\hline & (3.130) & (2.881) & (1.725) & (4.153) \\
\hline $\mathrm{CZ}$ & $\begin{array}{c}23.94 * * * \\
(5.545)\end{array}$ & $\begin{array}{c}\mathbf{1 3 8 . 8}^{* * * *} \\
(3.103)\end{array}$ & $\begin{array}{l}-1.237 \\
(2.910)\end{array}$ & $\begin{array}{c}19.36 * * * \\
(5.293)\end{array}$ \\
\hline \multirow[t]{2}{*}{ DK } & $17.45 * * *$ & 30.04*** & $5.885^{* * *}$ & $33.98 * * *$ \\
\hline & (3.824) & (3.033) & $(2.191)$ & $(7.501)$ \\
\hline EE & $18.30^{* * * *}$ & 48.95*** & 1.113 & $-12.32 * * *$ \\
\hline \multirow[t]{2}{*}{ FI } & $\begin{array}{c}(4.149) \\
22.24 * * *\end{array}$ & $\begin{array}{l}(3.754) \\
\mathbf{8 . 4 1 6 * *}\end{array}$ & $\begin{array}{c}(2.265) \\
1.005\end{array}$ & $\begin{array}{l}(3.897) \\
-0.388\end{array}$ \\
\hline & $(3.831)$ & $(3.847)$ & $(2.204)$ & $(5.223)$ \\
\hline FR & $\begin{array}{c}27.34 * * * \\
(7624)\end{array}$ & $\begin{array}{c}\mathbf{9 9 . 1 0}^{* * * *} \\
(3.291)\end{array}$ & $\begin{array}{c}-3.472 \\
(3.913)\end{array}$ & $\begin{array}{c}55.66 * * * \\
(12.02)\end{array}$ \\
\hline \multirow[t]{2}{*}{ GE } & 3.257 & $119.0^{* * * *}$ & $7.580^{* * *}$ & $13.48 * *$ \\
\hline & $\begin{array}{c}(5.093) \\
\mathbf{1 7 . 7 4 * * *}\end{array}$ & $\begin{array}{l}(3.132) \\
\mathbf{4 5 . 5 8 * * *}\end{array}$ & $\begin{array}{c}(2.696) \\
0.442\end{array}$ & $\begin{array}{c}(5.817) \\
6.556\end{array}$ \\
\hline GR & $(3.442)$ & $(2.662)$ & $(1.978)$ & (5.772) \\
\hline \multirow[t]{2}{*}{ HU } & 12.81* & $87.33^{* * *}$ & 0.235 & 12.58 \\
\hline & $\begin{array}{c}(6.568) \\
27.61 * * *\end{array}$ & $\begin{array}{l}(2.164) \\
\mathbf{2 8 . 0 0 * * *}\end{array}$ & (3.329) & $\begin{array}{l}(9.415) \\
-6.734 *\end{array}$ \\
\hline IE & $\begin{array}{c}\mathbf{2 7 . 6 1} \text { 1*** }^{(3.115)}\end{array}$ & $\begin{array}{c}28.000^{2 * 56} \\
(3.565)\end{array}$ & $\begin{array}{c}0.657 \\
(2.120)\end{array}$ & $\begin{array}{l}-6.734^{*} \\
(3.517)\end{array}$ \\
\hline \multirow[t]{2}{*}{ IT } & $8.446 * * *$ & $70.88 * * *$ & -0.406 & $30.78 * * *$ \\
\hline & $(1.873)$ & $(1.132)$ & (0.979) & (2.412) \\
\hline JP & 18.09* & $\begin{array}{l}156.1 \text { *** } \\
(3.231)\end{array}$ & $\begin{array}{l}-6.736 \\
(5.136)\end{array}$ & $\begin{array}{l}16.34 \\
(10.65)\end{array}$ \\
\hline \multirow[t]{2}{*}{ LT } & $\begin{array}{c}(10.13) \\
\mathbf{2 6 . 8 5 * * *}\end{array}$ & $\begin{array}{c}(3.231) \\
\mathbf{5 3 . 5 2 * * *}\end{array}$ & $\begin{array}{l}(5.136) \\
-1.552\end{array}$ & $\begin{array}{c}(10.65) \\
-6.030^{* *}\end{array}$ \\
\hline & $(2.064)$ & $(2.892)$ & (1.386) & (2.656) \\
\hline LV & $24.73 * * *$ & 46.01*** & -1.529 & -4.426 \\
\hline \multirow[t]{2}{*}{ LU } & $\begin{array}{c}(2.835) \\
16.73 * * *\end{array}$ & $\begin{array}{l}(3.169) \\
\mathbf{6 8 . 1 3 * * *}\end{array}$ & $\begin{array}{l}(1.667) \\
-1.854\end{array}$ & $\begin{array}{c}(2.987) \\
10.63\end{array}$ \\
\hline & $(4.110)$ & $(2.762)$ & (2.158) & (7.115) \\
\hline $\mathrm{NE}$ & $11.85 * *$ & $112.6 * * *$ & 0.123 & $\begin{array}{l}-0.718 \\
(6.507)\end{array}$ \\
\hline \multirow[t]{2}{*}{ NO } & $\begin{array}{l}(5.048) \\
19.32 * *\end{array}$ & $\begin{array}{l}(2.933) \\
25.93 * *\end{array}$ & $\begin{array}{c}(2.580) \\
6.999 * * *\end{array}$ & $\begin{array}{c}(6.507) \\
6.489\end{array}$ \\
\hline & (4.804) & $(5.031)$ & $(2.582)$ & $(4.404)$ \\
\hline PO & $25.95 * * *$ & $25.43 * * *$ & 3.008 & $15.58 * *$ \\
\hline \multirow[t]{2}{*}{ PT } & $\begin{array}{c}(3.795) \\
19.44 * * *\end{array}$ & $\begin{array}{c}(2.700) \\
\mathbf{3 8 . 8 3 * * *}\end{array}$ & $\begin{array}{c}(2.341) \\
1.985\end{array}$ & $\begin{array}{l}(7.849) \\
\mathbf{9 . 1 0 4 * * *}\end{array}$ \\
\hline & (2.139) & $(1.973)$ & $(1.242)$ & (3.046) \\
\hline \multirow[t]{2}{*}{ RO } & 5.827 & $61.54^{* * *}$ & $5.012 * *$ & $16.90 * * *$ \\
\hline & (3.945) & (2.618) & (2.072) & $(5.652)$ \\
\hline \multirow[t]{2}{*}{ SK } & $36.97 * * *$ & 92.04*** & $-7.209 * * *$ & 6.094 \\
\hline & $(4.967)$ & (3.302) & (2.664) & (6.064) \\
\hline SI & $\begin{array}{l}\mathbf{9 . 4 9 4 * * * *} \\
(2.508)\end{array}$ & $\begin{array}{c}\text { 121.1*** } \\
(2.573)\end{array}$ & $\begin{array}{c}0.260 \\
(1.470)\end{array}$ & $\begin{array}{l}-2.786 \\
(2.624)\end{array}$ \\
\hline ES & $28.81 * * *$ & $28.63^{* * *}$ & $-4.020 * * *$ & $6.557^{* * *}$ \\
\hline & $(1.794)$ & $(1.144)$ & $(0.951)$ & $(2.450)$ \\
\hline SE & $29.33^{* * *}$ & $46.37 * * *$ & 2.040 & $27.19 * * *$ \\
\hline & $(4.028)$ & $(4.256)$ & (2.309) & $(4.617)$ \\
\hline $\mathrm{CH}$ & $21.69 * * *$ & $87.89 * * *$ & 0.182 & $33.89 * * *$ \\
\hline & (3.202) & $(2.542)$ & $(1.787)$ & (5.742) \\
\hline UK & $22.42 * * *$ & $66.37 * * *$ & $3.990 * * *$ & $18.77 * * *$ \\
\hline & (2.574) & $(2.241)$ & (1.508) & (3.265) \\
\hline US & $\begin{array}{c}25.45 * * * \\
(4.500)\end{array}$ & $\begin{array}{c}43.31 * * * \\
(2.751)\end{array}$ & $\begin{array}{l}-0.349 \\
(2.516)\end{array}$ & $\begin{array}{c}8.987 \\
(9.572)\end{array}$ \\
\hline
\end{tabular}

All regressions controlled for age, gender, father at home, mother at home, immigrant status, second generation immigrant status, language spoken at home. Data for France on 'ability grouping' is missing. Standard errors are reported in brackets. 
Figures A2: Quantile effects of ability grouping on PISA scores and equality of educational opportunity (socio-economic gradient SEG)

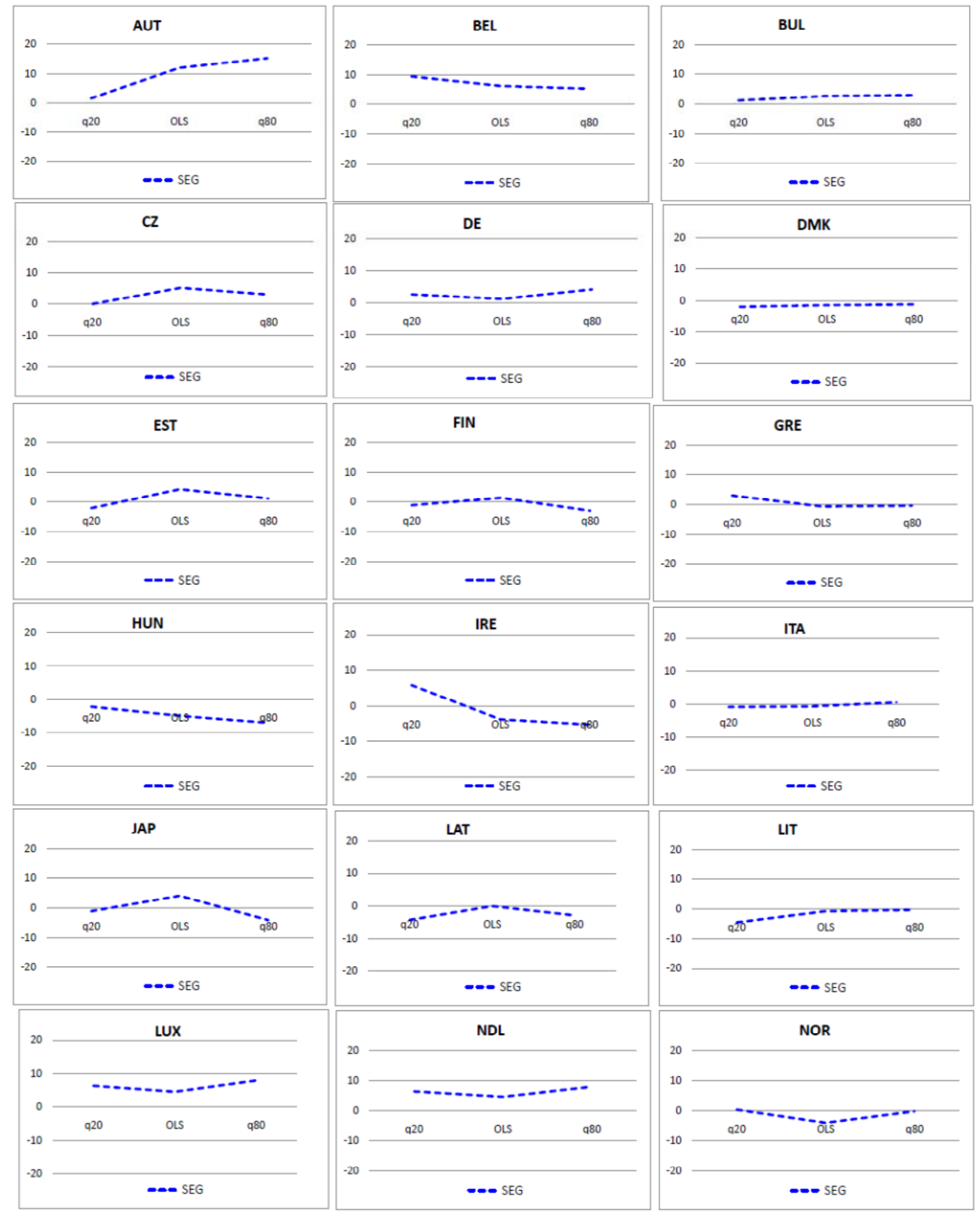



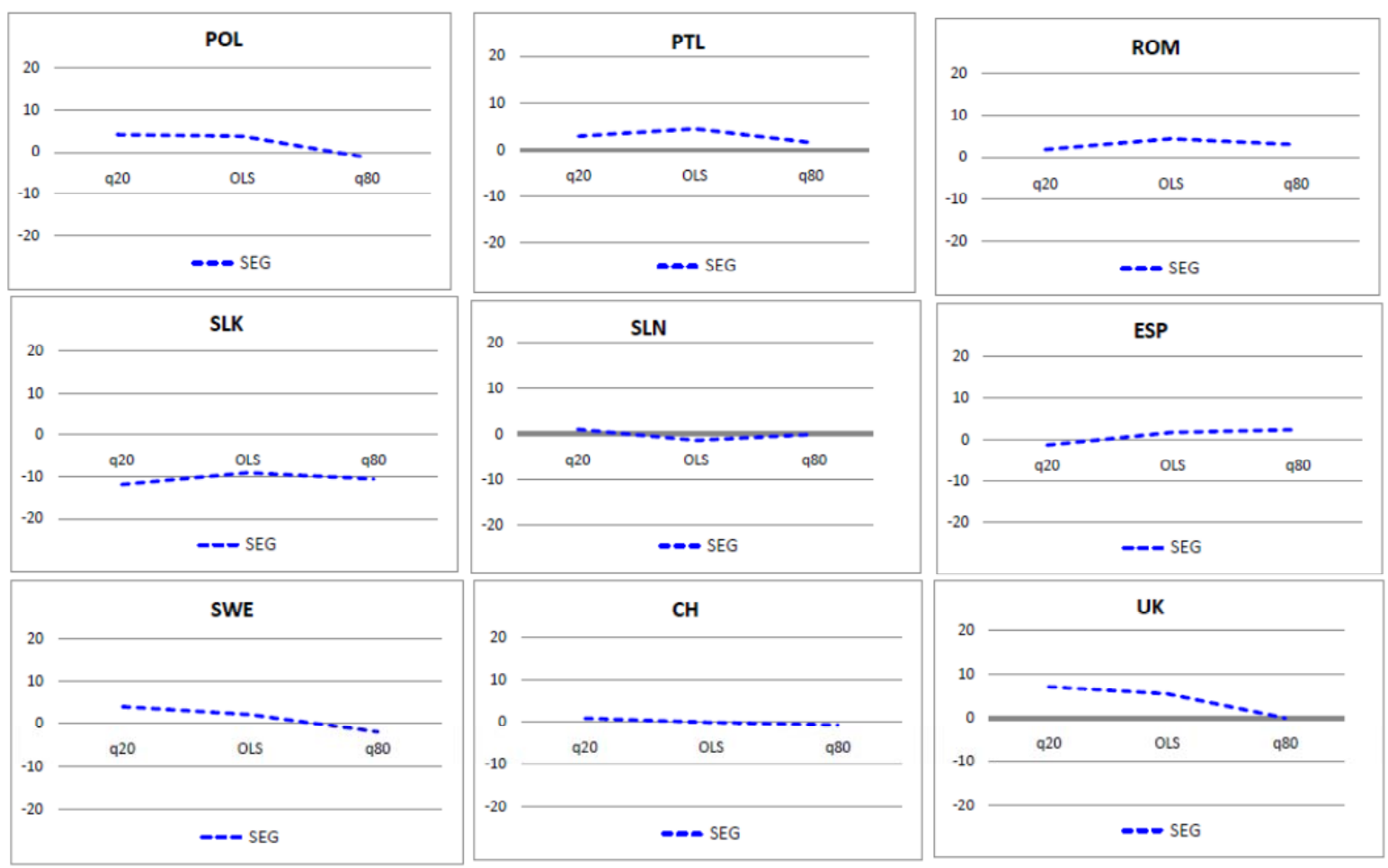

US

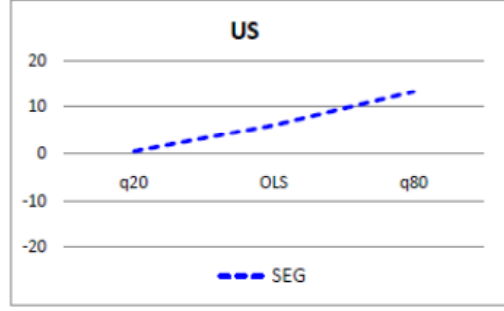


Figures A3: Quantile effects of pre-primary education on PISA scores and equality of educational opportunity (socio-economic gradient SEG)

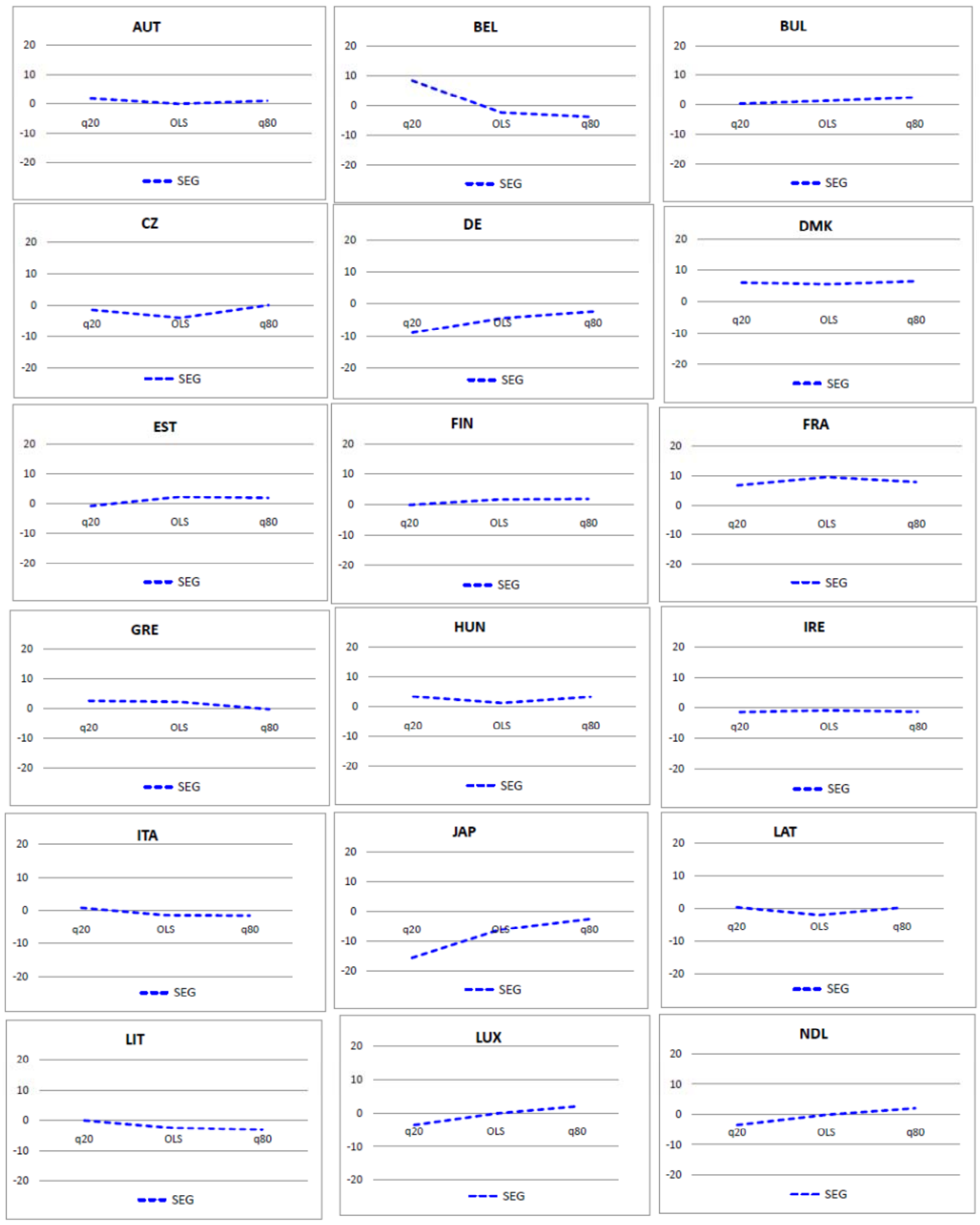



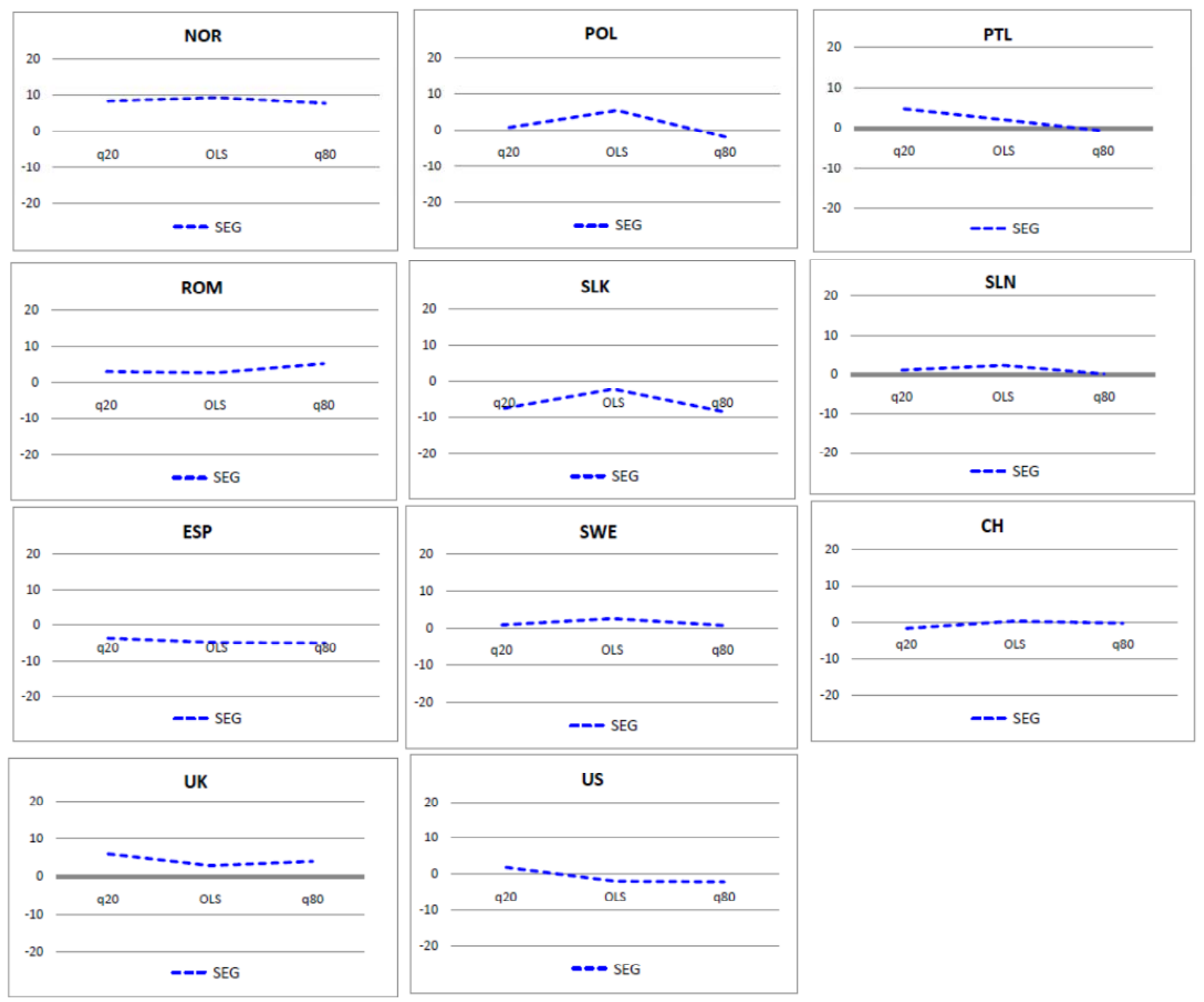